Maria Paula de Oliveira Valadares

\title{
Variabilidade genética de Bocavírus Humano isolado em Crianças com Doença Respiratória Aguda em São Paulo, Brasil
}

Tese apresentada ao Programa de Pós-Graduação Interunidades em Biotecnologia USP/Instituto Butantan/IPT, para obtenção de Título de Doutor em Biotecnologia. 


\section{Maria Paula de Oliveira Valadares}

\section{Variabilidade genética de Bocavírus Humano isolado em Crianças com Doença Respiratória Aguda em São Paulo, Brasil}

Tese apresentada ao Programa de PósGraduação Interunidades em Biotecnologia USP/Instituto Butantan/IPT, para obtenção de Título de Doutor em Biotecnologia.

Área de concentração: Biotecnologia

Orientador: Prof. Dr. Edison Luiz Durigon

São Paulo

2010 
DADOS DE CATALOGAÇÃO NA PUBLICAÇÃO (CIP)

Serviço de Biblioteca e Informação Biomédica do

Instituto de Ciências Biomédicas da Universidade de São Paulo

(C) reprodução total

\section{Valadares, Maria Paula de Oliveira.}

Variabilidade genética de bocavírus humano isolado em crianças com doença respiratória aguda em São Paulo, Brasil / Maria Paula de Oliveira Valadares. -- São Paulo, 2010.

Orientador: Edison Luiz Durigon.

Tese (Doutorado) - Universidade de São Paulo. Instituto de Ciências Biomédicas. Programa de Pós-Graduação Interunidades em

Biotecnologia USP/IPT/Instituto Butantan. Área de concentração:

Biotecnologia. Linha de pesquisa: Virologia molecular

Versão do título para o inglês: Genetic variability of human bocavirus isolated from children with acute respiratory disease in São Paulo, Brazil.

Descritores: 1. Biologia molecular 2. Bocavírus humano 3. Doença respiratória 4. Variabiidade genética 5 . Reação em cadeia por polimerase 5. Filogenia I. Durigon, Edison Luiz II. Universidade de São Paulo. Instituto de Ciências Biomédicas. Programa de Pós-

Graduação Interunidades em Biotecnologia USP/IPT/Instituto Butantan III. Título. 
UNIVERSIDADE DE SÃO PAULO

Programa de Pós-Graduação Interunidades em Biotecnologia

Universidade de São Paulo, Instituto Butantan, Instituto de Pesquisas Tecnológicas

Candidato(a):

Maria Paula de Oliveira Valadares.

Título da Tese:

Variabilidade genética de bocavírus humano isolado em crianças com doença respiratória aguda em São Paulo, Brasil.

Orientador(a): $\quad$ Edison Luiz Durigon.

A Comissão Julgadora dos trabalhos de Defesa da Tese de Doutorado, em sessão pública realizada a considerou

\section{( ) Aprovado(a)}

\section{( ) Reprovado(a)}

Examinador(a): Assinatura:

Nome:

Instituição:

Examinador(a): Assinatura:

Nome:

Instituição:

Examinador(a): Assinatura:

Nome:

Instituição:

Examinador(a): Assinatura:

Nome:

Instituição:

Presidente: Assinatura:

Nome:

Instituição: 
São Paulo, 27 de abril de 2010.

\section{PARECER 937/CEP}

A Comissão de Ética em Pesquisas com Seres Humanos do ICB, na sessão de 27.04.2010 ANALISOU o projeto intitulado: "Variabilidade genética de bocavírus humano isolado em crianças com doença respiratória aguda em São Paulo, Brasil ${ }^{3}$ sob responsabilidade de execução dos autores Prof. Dr. EDISON LuIz DuRIGON e a aluna MARIA PAUla de Oliveira VALADARES.

$$
\text { Informo que o presente projeto prevê o uso de material biológico }
$$
armazenado, obtido de seres humanos mas que, após processamento, consiste, basicamente, de material viral. A Comissão requer que essa cultura seja cadastrada junto à mesma e que projeto seja considerado Isento, bem como todos os demais que se utilizarem desse tipo de coleção. Quando pertinente, solicitar o CERTIFICADO DE ISENÇÃO

Atenciosamente,

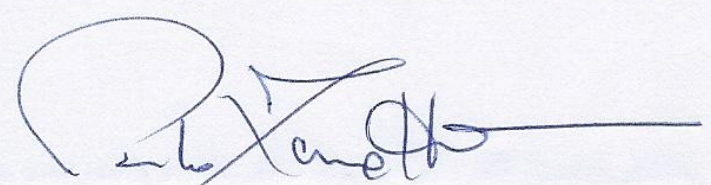

Prof. Dr. PAOLO MARINHO ANDRADE ZANOTTO

Coordenador da Comissão de Ética em

Pesquisas com Seres Humanos - ICB/USP 
Decl. CEPSH.71/10.

\section{DECLARA Ç $\tilde{A} O$}

Em adendo ao Parecer 937/CEP de 27.04.2010, informo que o referido projeto foi considerado isento por não existir manipulação diretamente com seres humanos.

São Paulo, 29 de junho de 2010.

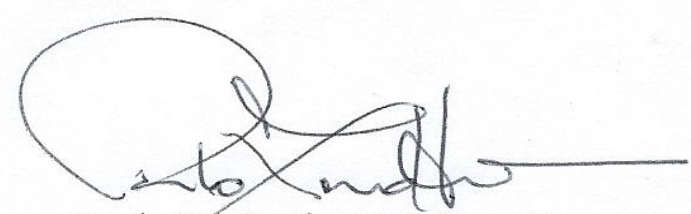

Prof. Dr. Paolo M.A.Zanotto

Coordenador da Comissão de Ética em Pesquisas com Seres Humanos - ICB /USP 
As três pessoas mais importantes da minha vida: Neide, "Dona" Maria (in memoriam) e "Seu" Mauro (in memoriam). Sem o amor de vocês NADA teria sido possível. 


\section{AGRADECIMENTOS}

Primeiramente a Deus, que é tão generoso comigo de diversas formas.

Ao meu orientador, Professor Dr. Edison Luiz Durigon, obrigada pela paciência, boa vontade, carinho, amizade e por acreditar em mim.

A Prof. Dra. Danielle Bruna, por estar sempre presente, e por sua amizade, apoio, carinho, e tempo que dedicou a mim, sem você eu não teria conseguido.

A Prof. Dra. Maria Luiza Barbosa e a Raquel Negrão pela contribuição, ajuda e carinho.

Aos colegas do laboratório de Virologia Clínica e Molecular do ICB: Adélia, Angélica, Carolzinha, César, Cláudia, Camila, Dyana, Fábio, Felipe, Hildener, Jansen, Juliana, Larissa Carvalho, Larissa, Lilian, Lilia Dutra, Luciano, Miguel, Patrícia, Priscila, Renata, Prof. Dra Silvana, Tati, Teca, Prof. Dra. Viviane, Zezinho e tantos outros que durante esses anos estiveram trabalhando, estudando e se divertindo ao meu lado.

A "FAM", Instituição da qual fazem parte pessoas especiais que tornaram-se essenciais em minha vida, obrigada por existirem, aguentarem, incentivarem minhas loucuras e partilharem suas loucuras comigo por mais de uma década. Juntos ainda vamos dominar o mundo.

Aos meus amigos: Ariane, André "Besouro", Bruno, Claudinho, Danila, Débora, Estevam "Jackie", Fátima, Fernando Augusto, Giceli, Glaucia, Juliana Fujimoto, "seu" João, Kadu, Kelly, Marinha, Priscilla, Rodrigo "Otouto", Rogério, Sarah, Simone, Thales, Virgínia, Mestre Jedi Serginho (e as mágicas que fez na escala através do uso da "Força), meu grande amigo Eduardo "Du" (que veio em meu resgate e registrou sua contribuição). A todos vocês obrigada pelo apoio, companheirismo, incentivo, amizade e momentos que fazem minha vida especial.... Amo muito vocês. 
A minha família, meus tios Mauro e Luiza, meus tios-avós Artur e Terezinha, meus primos Rodrigo e Ana Cláudia, a madrinha Cristina "Tati", e as duas luzinhas da minha vida André e Isabela... obrigada pelo apoio e amor.

E finalmente a minha Mãe, Mulher cujo exemplo de caráter, inteligência, disposição, desprendimento, dedicação e amor moldaram minha personalidade. Tudo que conquistei e que ainda conquistarei, foi e será, graças a você, e é impossível descrever em palavras o amor e gratidão que lhe dedico. Tenho orgulho de ser sua filha.

E a todos que direta ou indiretamente contribuíram para a realização deste trabalho...

Obrigada. 
"Para ser grande, sê inteiro: nada Teu exagera ou exclui. Sê todo em cada coisa. Põe quanto és No mínimo que fazes. Assim em cada lago a lua toda Brilha, porque alta vive." Fernando Pessoa (Ricardo Reis) 


\section{RESUMO}

Valadares MPO. Variabilidade genética de Bocavírus Humano isolado em crianças com doença respiratória aguda em São Paulo, Brasil [Tese (Doutorado em Biotecnologia)]. São Paulo: Instituto de Ciências Biomédicas da Universidade de São Paulo; 2010.

O HBoV é um novo parvovirus que foi isolado pela primeira vez em 2005 nas secreções respiratórias de pacientes humanos que tiveram pneumonia. É associado a doenças do trato respiratório superior e doença gastrointestinal em pacientes adultos e pediátricos, desde a sua descoberta na Suécia e posteriormente em diversos países no Mundo. Quase todos os estudos foram realizados em amostras de secreção do trato respiratório, normalmente, de crianças com menos de 2 anos de idade, com infecção respiratória e as taxas de prevalência variaram de 1,5\% a $19 \%$ nos diferentes países. A Análise filogenética deste novo vírus demonstrou que tratava-se de um parvovirus, mais estreitamente relacionado ao parvovirus bovino $\mathrm{e}$ ao minuto vírus canino e por isso foi denominado Bocavirus Humano. A variabilidade genética do $\mathrm{HBoV}$ é baixa e estudos filogenéticos indicam que duas linhagens circulam paralelamente ao redor do mundo. Entretanto, como ainda é um vírus relativamente novo, devem se feitos estudos mais detalhados de suas variantes. Em nosso estudo, com a finalidade de determinar a prevalência e conhecer a variabilidade genética do HBoV circulante, foram analisados de janeiro de 2008 a fevereiro de 2010, 985 amostras de aspirado de nasofaringe de crianças com menos de 2 anos de idade, com doença respiratória aguda, internadas no Hospital da Santa Casa de Misericórdia de São Paulo. Pela técnica de PCR, obtivemos $47(4,8 \%)$ amostras positivas para HBoV e dessas 27 amostras apresentaram coinfecção com outros vírus respiratórios, 45 amostras foram seqüenciadas na região da VP1/VP2 de um fragmento de 658 nt. A análise filogenética das amostras brasileiras quando comparada com seqüência do genBank representativas de vários países mostrou a circulação apenas da espécie 1 de HBoV semelhantes aos que circulam no Japão e Taiwan. A variabilidade genética entre as nossas amostras foram inferiores a $2 \%$, tanto entre si como quando comparadas com as amostras do genBank do mesmo genótipo.

Palavras-chave: Bocavírus Humano. Biologia Molecular. Variabilidade Genética. Reação em Cadeia da Polimerase. Doença Respiratória. Filogenia. 


\begin{abstract}
Valadares MPO. Genetic Variability of Human Bocavirus isolated from children with Acute Respiratory Disease in Sao Paulo, Brazil. [Ph. D. Thesis (Biotechnology)]. São Paulo: Instituto de Ciências Biomédicas da Universidade de São Paulo; 2010.

$\mathrm{HBoV}$ is a new parvovirus which was first isolated in 2005 from respiratory secretions from human patients who had pneumonia. It has been associated with respiratory and gastrointestinal diseases in adult and pediatric patients since its discovery in Sweden and later in several countries worldwide. Almost all studies were performed on samples of secretions from the respiratory tract, usually in children under 2 years of age, and prevalence rates vary from $1.5 \%$ to $19 \%$ in different countries. The phylogenetic analysis of this new virus showed that it was a parvovirus, more closely related to bovine parvovirus and canine minute virus, and therefore called Human Bocavirus. The genetic variability of $\mathrm{HBoV}$ is low and phylogenetic studies indicate that there are two strains circulating alongside around the world. However, as it is still a relatively new virus, more detailed studies of its variants should be carried out. In our study, 985 samples of nasopharyngeal aspirate from children under 2 years old with acute respiratory disease, patients at Santa Casa de Misericordia Hospital, São Paulo, were analyzed from February 2008 to February 2010 in order to determine the prevalence and genetic variability of $\mathrm{HBoV}$ stock. Using the PCR method, we obtained 47 (4.8\%) positive samples for HBoV from which 27 showed coinfection with other respiratory viruses; 45 samples from a fragment of 658 nt were sequenced in the VP1/VP2 region. The phylogenetic analysis, when compared with GenBank sequences representing several countries, showed the presence in our samples of species 1 of HBoV similar to those circulating in Japan and Taiwan. Genetic variation in our samples were below $2 \%$, both among themselves and when compared with samples from the GenBank of the same genotype.
\end{abstract}

Key Words: Human Bocavirus, Molecular Biology, Genetic Variability, Polymerase Chain Reaction, Respiratory, Phylogeny. 


\section{LISTA DE ABREVIATURAS E SIGLAS}

Aa: Aminoácido

AAV: Vírus adeno associado (do ingl. Adeno associated virus).

ANF: Aspirado de nasofaringe.

B19: Parvovírus B19.

BPV: Parvovírus bovino (do ingl. bovine parvovirus)

BR: Brasil

${ }^{\circ} \mathbf{C}$ : Graus Celsios.

CoV: Coronavírus.

DNA: Ácido desoxirribonucléico (do ingl. Deoxynucleic acid).

$$
\text { : Deoxir - trifosfatados (dATP, dTTP, dCTP, dGTP) (do }
$$

ingl. Deoxynucleoside triphosphates).

EDTA: Ácido etilenodiaminotetracético (do ingl. Ethylenediaminetetraacetic acid).

IA/H1N1: Influenza A pandêmico (hemaglutinina 1, neuraminidase 1).

HBoV: Bocavírus humano (do ingl. Human bocavirus).

HAdV: Adenovírus humano (do ingl. Human Adenovirus), coronavírus (CoV), adenovírus (HAdV)

HRSV ou RSV: Vírus Sincicial Respiratório Humano (do ingl. Human respiratory syncytial virus).

HSCM-SP: Hospital da Santa Casa de Misericórdia de São Paulo.

ICTV: Comite Internacional de Taxonomia de Vírus (do ingl. International Committee of Taxonomy of Viruses).

Ig: Imunoglobulina.

IA: Influenza A.

IB: Influenza B.

IRA: Infecção respiratória aguda.

ITR: Infecção do trato respiratório.

Kb: 1000 pares de bases.

MCV: Minuto vírus canino (do ingl. Minute canine virus)

Min: minuto.

$\mathrm{Ng}$ : nanograma.

nm: nanômetros.

nt: Nucleotídeos. 
ORF: Janela de Leitura (do Ingl. Open reading frame).

P1, P2, P3: Parainflenza 1, 2 ou 3.

$\mathrm{Pb}$ : Pares de bases.

PBS: Solução salina tamponada com fosfatos.

PCR: Reação em cadeia da polimerase (do ingl. Polymerase chain reaction).

pH: Potencial hidrogeniônico.

pmol: Picomol.

Primer: Oligonucleotídeo iniciador.

RhV: Rinovírus (do ingl. Rhinovírus).

RNAse: Ribonucleose.

RPM: Rotações por minuto.

Seg: segundo.

SP: São Paulo

ST1 e ST2: Estocolmo 1 e 2 (do inlg. Stocolm), isolados oroginais de HBoV (Allander et al., 2005).

TBE: Tampão tris-borato EDTA.

Tris: Tris (hidroximetil) aminometano.

USP: Universidade de São Paulo

UV: Ultravioleta.

UTI: Unidade de Terapia Intensiva. 


\section{LISTA DE SIMBOLOS}

\section{Aminoácidos}

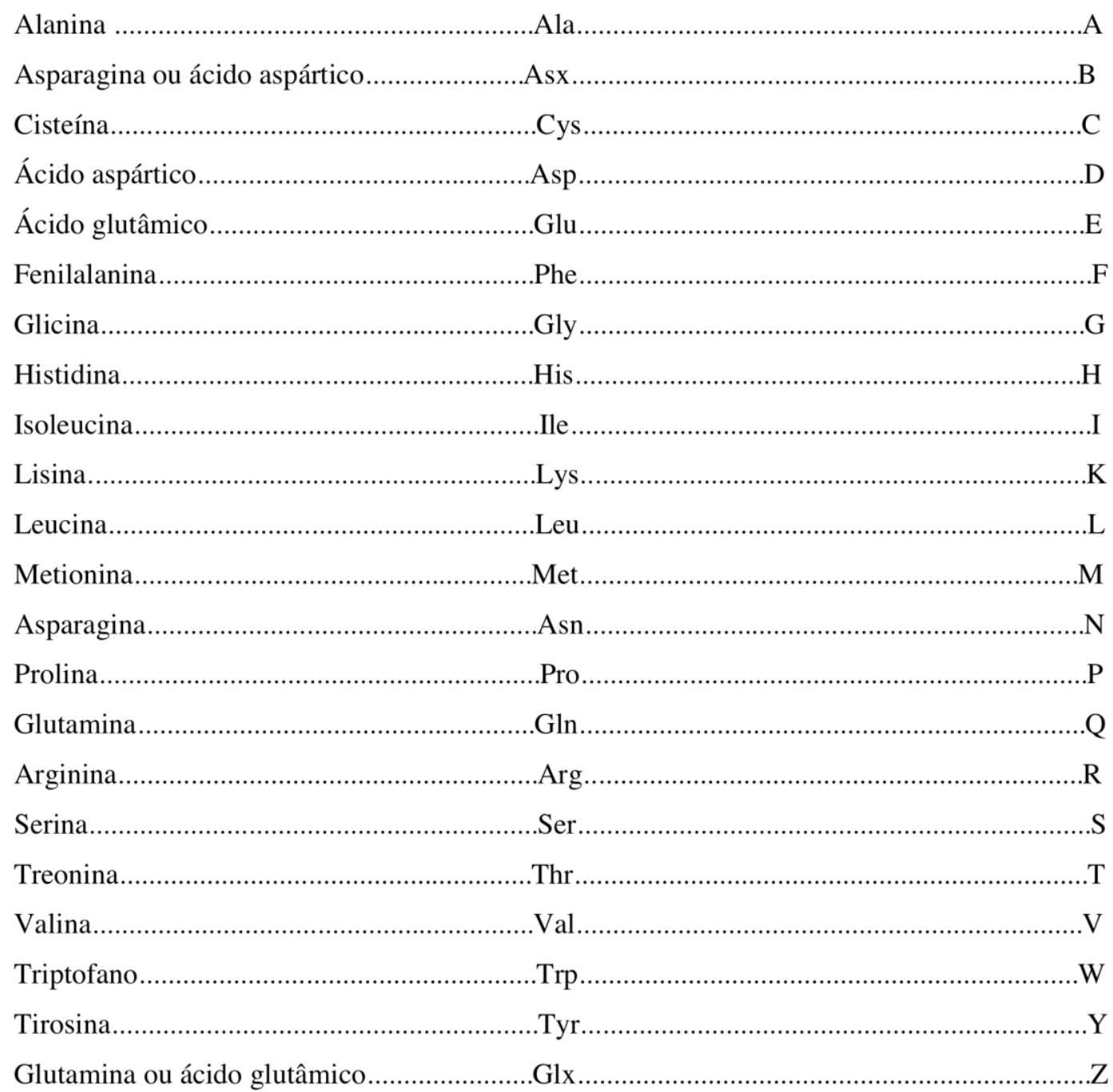

\section{Bases nitrogenadas dos nucleotídeos}

Adenina




\section{SUMÁRIO}

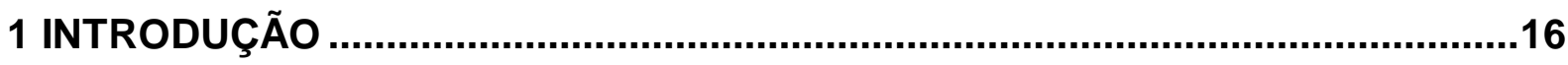

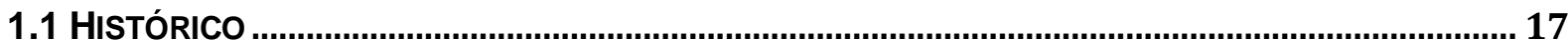

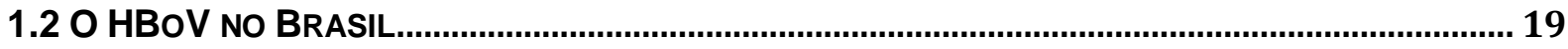

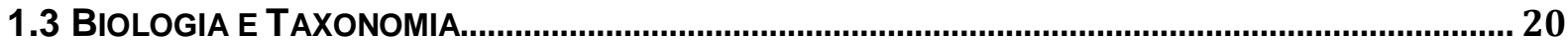

1.4 ORGANIZAÇÃO GENÔMICA

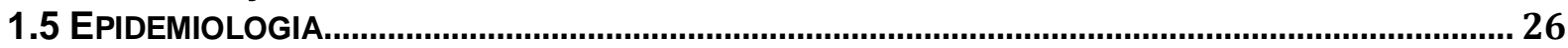

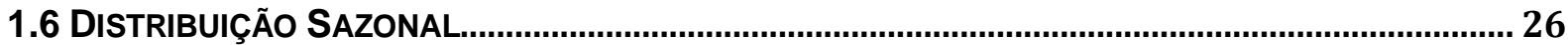

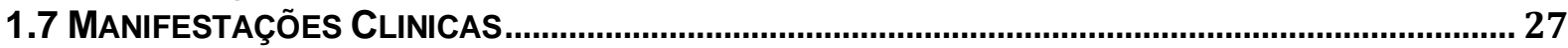

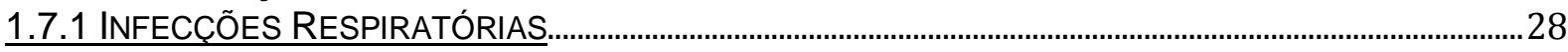

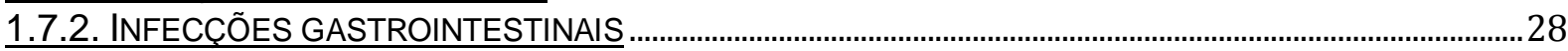

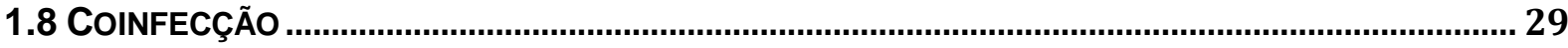

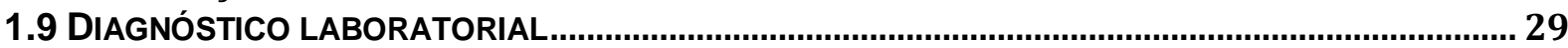

2 OBJETIVOS ....................................................................................................31

3 MATERIAL E MÉTODOS .................................................................................32

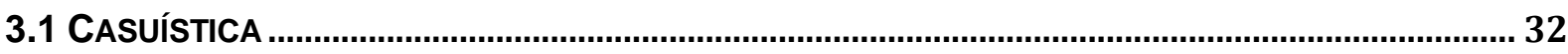

3.2 Diagnóstico LABORATORIAL DA INFECÇÃO POR HBOV E ANÁLISE GENÉTICA DAS

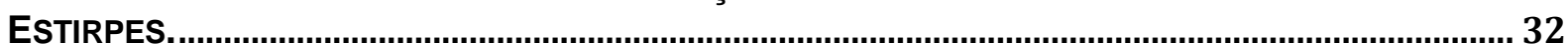

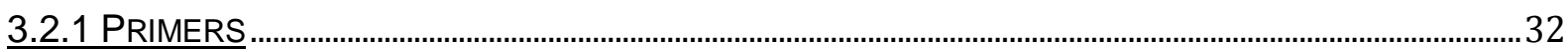

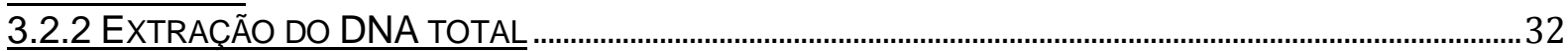

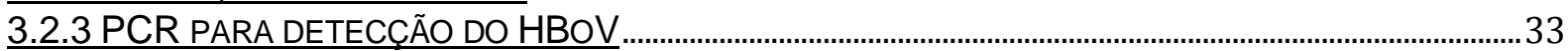

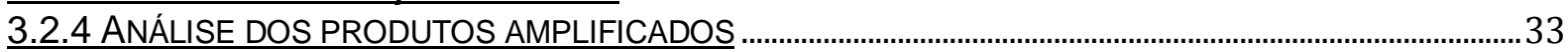

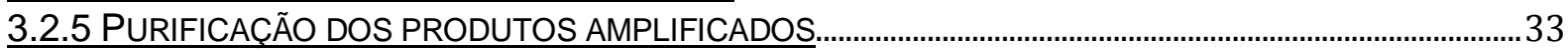

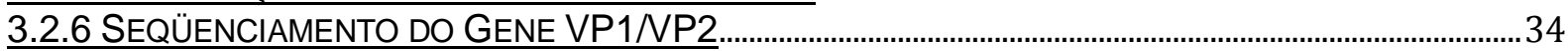

3.2.7 PROCESSAMENTO E ALINHAMENTO DAS SEQÜÊNCIAS DO GENE VP1/VP2 …...............................34

3.2.8 GENOTIPAGEM DO BOCAVÍRUS HUMANO

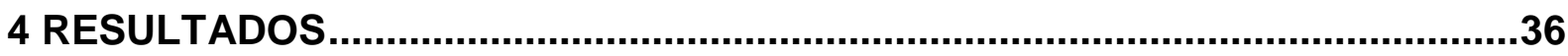

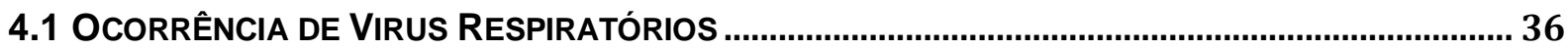

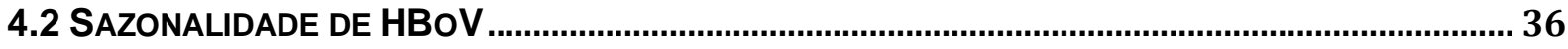

4.3 COINFECÇÃO

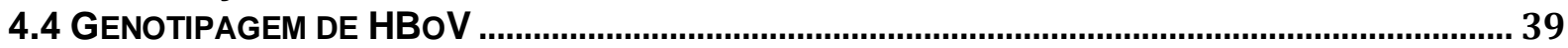

4.5 ANÁLISE DA VARIABILIDADE DE NUCLEOTIDEOS INTER E INTRA-GRUPO.................................. 40

4.6 ANÁLISE DA VARIABILIDADE DE AMINOÁCIDOS

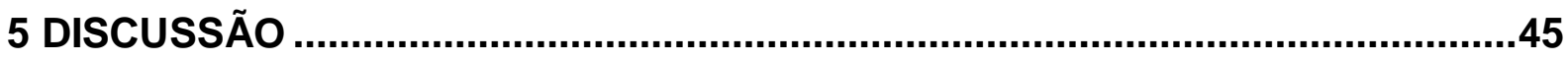

6 CONCLUSÕES ..........................................................................................4

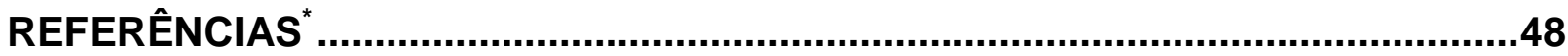




\section{INTRODUÇÃO}

As infecções do trato respiratório (ITR) são as principais causas de hospitalização de crianças em todo mundo. Nos países em desenvolvimento a incidência, gravidade e letalidade causada pelas ITR, principalmente, pela pneumonia, é elevada (Selwyn, 1990). Ainda, que a letalidade por pneumonia seja bastante reduzida através do tratamento com antibióticos $40 \%$ desses casos são causados por vírus que são resistentes a estes medicamentos (Benguigui, 1994; Pinner et al., 1996).

O avanço em métodos moleculares permitiu a identificação de diferentes patógenos respiratórios, incluindo o metapneumovírus humano (hMPV), coronavírus (CoV), poliomavírus e do bocavírus humano (HBoV). Embora as doenças causadas por vírus respiratórios, no passado, tenham sido subestimadas, existe agora uma crescente valorização do papel que estes vírus desempenham na comunidade e em infecções intra-hospitalares (Chow e Esper, 2009).

A identificação de um vírus no trato respiratório pode ter implicações para outras doenças, além de ITR. Já que os vírus têm opções limitadas de transmissão entre hospedeiros, muitos vírus inicialmente não associados com sintomas respiratórios são, no entanto, transmitidos através do trato respiratório, ao exemplo de enterovírus e parvovírus B19. Portanto, o trato respiratório pode conter vírus desconhecidos associados com sintomas leves ou severos.

$\mathrm{Na}$ Suécia em 2005, durante um estudo em amostras provenientes do trato respiratório de pacientes com pneumonia foi identificado um novo vírus chamado bocavírus humano (HBoV) (Allander et al., 2005). Desde a sua descoberta tem sido associado a infecções respiratórias e gastrointestinais principalmente em crianças.

O HBoV pertence a família Parvoviridae (parvovírus), subfamilia Parvovirinae, gênero Bocavirus. Os membros do gênero bocavírus anteriomente descritos são o parvovírus bovino (BPV) e o minutovírus canino (MVC), o HBoV é o primeiro do gênero Bocavírus associado a infecções em humanos (Allander et al., 2005)

Como os demais parvovírus possui uma fita simples de DNA não envelopado, seu capsídeo tem formato icosaédrico, o genoma é formado por duas janelas de leitura (ORFs) principais que codificam uma proteína não-estrutural chamada NS1 e duas proteínas de capsídio chamadas VP1 e VP2 (Berns, 1996). 
Em 2009 dois estudos relataram a descoberta de dois novos vírus muito semelhantes ao $\mathrm{HBoV}$, os quais foram chamados provisoriamente de HBoV-2 (Kapoor et al., 2009) e HBoV-3 (Arthur et al., 2009), sendo que o nome HBoV-1 refere-se ao bocavírus original descrito por Allander em 2005.

\subsection{Histórico}

Allander et al. em 2005 na Suécia, analisando secreções respiratórias de pacientes com pneumonia diagnosticados negativamente para todos os vírus respiratórios estudados, realizaram uma amplificação randômica do material genético seguida de análise de bioinformática. Foram utilizados dois conjuntos de amostras de aspirados de nasofaringe (ANS), provenientes de amostras selecionadas aleatoriamente. Ambos foram submetidos a ultracentrifugação, microfiltração e tratamento com DNAse. O material genético encapsulado foi extraído, amplificado, clonado em um vetor $\mathbf{p C R} \circledast$-Blunt e sequenciados. Os clones dos dois conjuntos foram então sequenciados bidirecionalmente e as sequências foram submetidas a análises de bioinformática que categorizaram os clones em humano, bacterial, fago, vírus e sequências desconhecidas. As sequências virais perfaziam um total de $20 \%$ dos clones e eram pertencentes a sete espécies diferentes de vírus. A analise de aminoácidos mostrou que estas duas sequências eram similares ao BPV e o MVC sendo denominadas Estocolmo 1 e 2 (ST1 e ST2). Foram construídas árvores filogenéticas baseadas nos alinhamentos dos isolados ST1 e ST2 e os vírus da subfamília Parvovirinae, os resultados das sequências de nucleotídeos e aminoácidos das duas maiores ORFs confirmaram que os isolados agrupavam-se com o BPV e o MVC. Este estudo levou a conclusão de que tratavase de um novo parvovirus e devido a sua relação próxima ao parvovirus bovino e ao minuto vírus canino foi denominado de Bocavirus Humano. A variabilidade genética do HBoV é baixa e estudos filogenéticos indicam que dois genótipos circulam paralelamente ao redor do mundo (Allander et al., 2005).

Desde da descoberta do bocavirus, diversos estudos foram publicados investigando as características do HBoV, os estudos pioneiros de cada país foram sintetizados na tabela 1. 
Tabela 1 - Países em que o HBoV foi relatado e ano da primeira publicação.

\begin{tabular}{lll}
\hline País & Ano da Publicação & Autor \\
\hline Suécia & 2005 & Allander et al. \\
África do Sul & 2006 & Smults et al. \\
Alemanha & 2006 & Weissbrich et al. \\
Austrália & 2006 & Sloots et al. \\
Canadá & 2006 & Bastien et al. \\
Córeia & 2006 & Choi et al. \\
EUA & 2006 & Kesebir et al. \\
França & 2006 & Foulongne et al. \\
Inglaterra & 2006 & Manning et al. \\
Japão & 2006 & Ma et al. \\
Jordânia & 2006 & Kaplan et al. \\
Brasil & 2007 & Albuquerque et al. \\
China & 2007 & Qu et al. \\
Espanha & 2007 & Vicente et al. \\
Holanda & 2007 & Monteny et al. \\
Itália & 2007 & Maggi et al. \\
Suiça & 2007 & Regamey et al. \\
Tailândia & 2007 & Fry et al. \\
Dinamarca & 2008 & Linstow et al. \\
Israel & 2008 & Hindiyeh et al. \\
Noruega & 2008 & Christensen \\
Chile & 2009 & Moreno et al \\
Singapura & 2009 & Tan et al. \\
\hline & &
\end{tabular}

Recentemente foram identificados dois novos vírus muito semelhantes ao $\mathrm{HBoV}$, os quais foram chamados provisoriamente de HBoV-2 e HBoV-3, sendo que o nome HBoV-1 refere-se ao bocavírus original descrito por Allander em 2005.

O HBoV-2, relatado pela primeira vez em janeiro de 2009 , tendo sido detectado em amostras fecais após análise de partículas virais resistentes a nuclease. Os amplicons obtidos por PCR randômico foram clonados em um plasmídio, seqüenciados e comparados com seqüências do GenBank. A análise filogenética do HBoV-2 mostrou 78\%, 67\% e $80 \%$ de similaridade de aminoácidos com as proteínas NS1, NP1 e NP1/NP2 do HBoV-1 respectivamente (Kapoor et al., 2009).

O HBoV-3 foi descoberto por Arthur et al. em abril de 2009 na Austrália. Utilizando métodos similares aos aplicados nas descobertas do HBoV-1 e HBoV-2, foram analisadas amostras fecais sendo encontrados simultaneamente o HBoV-2 e o HBoV-3. A análise do seu genoma mostrou que o HBoV-3 possui alta homologia na região codificadora das proteínas não-estruturais (NS1, NP1) do HBoV-1, por outro lado nas regiões que codificam as proteínas estruturais (VP1/VP2) a similaridade é maior com o HBoV-2, indicando que o HBoV-3 pode ser produto da 
recombinação entre o HBoV-1 e o HBoV-2 (figura 01), e essa hipótese foi fortalecida pela descoberta de um possível sítio de recombinação. Assim como ० HBoV-2 o genoma do HBoV-3 é diferente do HBoV-1 o suficiente para explicar porque não foram detectados com o uso dos primers utilizados para HBoV-1.

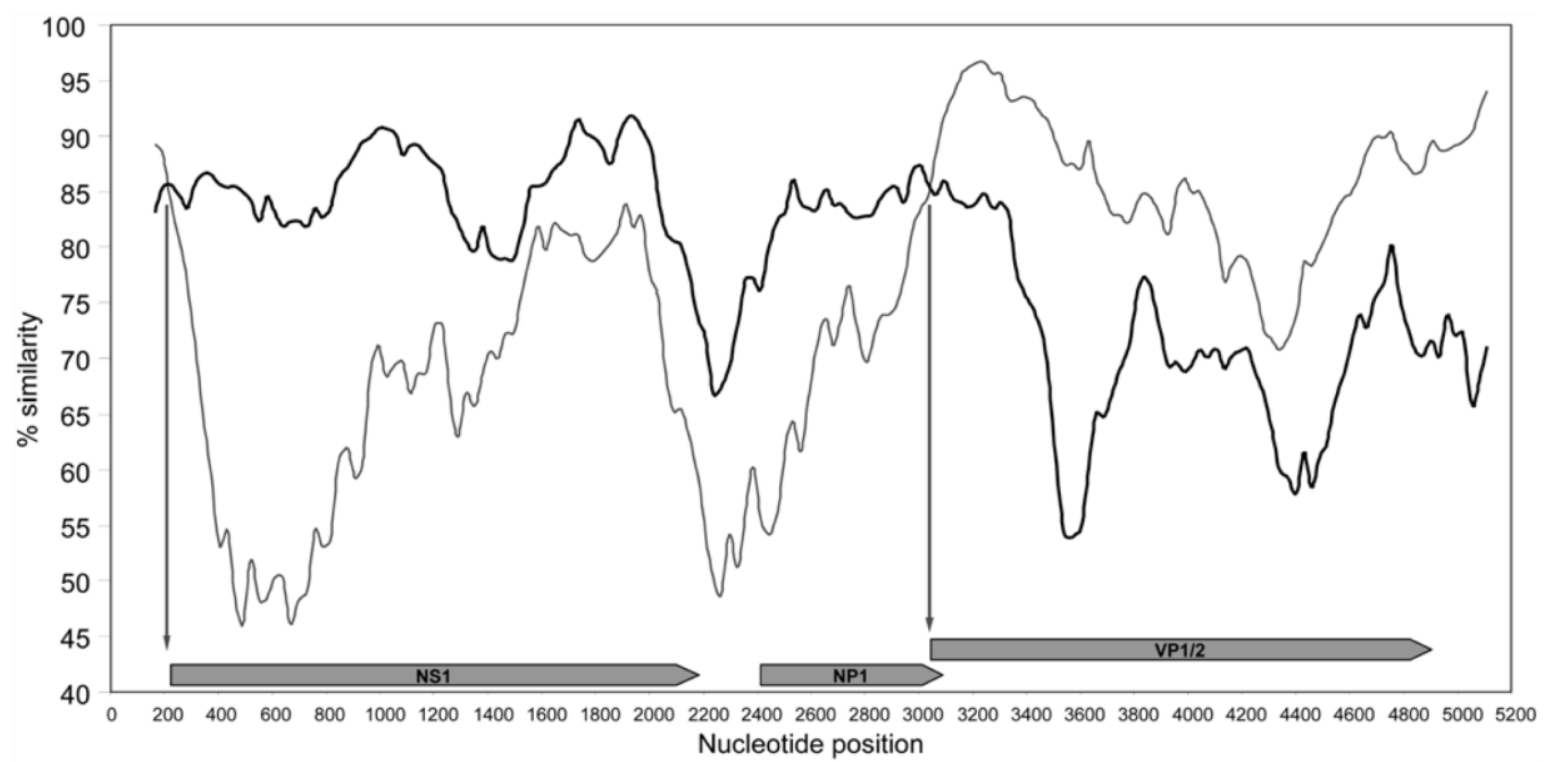

Figura 1 - Gráfico de similaridade do HBoV-3 em relação ao HBoV (linha preta) e HBoV-2 (linha cinza) mostrando a porcentagem de similaridadeao longo dos genomas. Os sítios de recombinação aproximados são indicados pelo cruzamento das linhas.

FONTE: Arthur et al. (2009).

\subsection{HBoV no Brasil}

No Brasil o HBoV foi primeiramente relatado em 2007 no Rio de Janeiro em amostras fecais de crianças com gastroenterite, do total de amostras $2 \%$ eram positivas para HBoV e $21,4 \%$ apresentaram coinfecção com rotavírus, adenovírus e norovírus (Albuquerque et al., 2007). Estudos realizados em Ribeirão Preto (Gagliardi et al., 2009), Rio de Janeiro (Albuquerque et al., 2009) e Bahia (Souza et al., 2010) confirmaram estes achados.

Recentemente, no Brasil, foi relatada a circulação do HBoV-2 e do HBoV-3 encontrado em pacientes com gastroenterite aguda, $\mathrm{HBoV}-3$ foi detectado $0,6 \%$ das amostras e o HBoV-2 em $20,8 \%$, de 144 amostras positivas para HBoV-1 e HBoV-2 selecionadas aleatóriamente. Além de 1,2\% de ocorrência para o HBoV-1 (Santos et al., 2010), este foi o primeiro estudo a encontrar o HBoV-3 fora da Austrália. Em São Paulo um estudo sobre infecção intrahospitalar descreveu casos de infecção por 
HBoV, em crianças menores de 2 anos (Durigon et al., 2010). Os dados sobre as publicações brasileiras estão detalhados na tabela 2 .

Tabela 2 - Publicações sobre o HBoV no Brasil.

\begin{tabular}{|c|c|c|c|c|c|}
\hline $\begin{array}{l}\text { Data } \\
\text { Publicação }\end{array}$ & Local & Autor & Amostra & $\begin{array}{l}\text { Ocorrência } \\
\text { (\%) }\end{array}$ & $\begin{array}{l}\text { Coinfecção } \\
(\%)\end{array}$ \\
\hline 2007 & $\begin{array}{l}\text { Rio de } \\
\text { Janeiro }\end{array}$ & Albuquerque et al & Fecal & $\begin{array}{l}36,8(7 / 19) \\
\text { HBoV1 }\end{array}$ & 28,6 \\
\hline Jan/2009 & $\begin{array}{l}\text { Ribeirão } \\
\text { Preto }\end{array}$ & Gagliardi et al. & ANF & 10,5 HBoV1 & 81 \\
\hline Abril/2009* & Salvador & Souza et al. & ANF & 6,06 HBoV1 & 50 \\
\hline Maio/2009 & $\begin{array}{l}\text { Rio de } \\
\text { Janeiro }\end{array}$ & Albuquerque et al. & ANF & 14 HBoV1 & 21,4 \\
\hline Março/2010 & $\begin{array}{l}\text { Rio de } \\
\text { janeiro }\end{array}$ & Santos et al. & Fecal & $\begin{array}{l}1,2 \mathrm{HBoV} 1 \\
20,8 \mathrm{HBoV} 2 \\
0,6 \mathrm{HBoV} 3\end{array}$ & - \\
\hline Abril/2010 & $\begin{array}{l}\text { São } \\
\text { Paulo }\end{array}$ & Durigon et al. & ANF & 10,7 HBoV1 & 51,1 \\
\hline
\end{tabular}

* Publicação eletrônica

\subsection{Biologia e Taxonomia}

O HBoV pertence a família Parvoviridae (parvovírus), subfamilia Parvovirinae, gênero Bocavirus (Chow e Esper, 2009).

A família Parvoviridae é dividida em duas subfamílias, Densovirinae que infecta somente artropodes e a subfamília Parvovirinae que infecta mamíferos e pássaros. Os vírus da subfamília Parvovirinae são subdivididos em cinco gêneros pelo Comite Internacional de Taxonomia de Vírus (ICTV): Parvovirus, Erytrovirus, Dependovirus, Amdovirus e Bocavirus. Os únicos parvovírus humanos patogênicos conhecidos até o final do milênio passado eram o pavovírus B19, pertencente ao gênero Erytrovirus, portanto o HBoV é o segundo parvovírus associado a infecções em seres humanos (Allander et al., 2005).

Os membros da família Parvoviridae são vírus não envelopados, possuem capsídios de formato icosaédrico e com diâmetros que variam de 18 a 26 nm, são os 
menores vírus conhecidos. O capsídeo consiste de 60 capsomeros e cada um deles tem o formato de um quadrilátero (Berns et al., 1996).

O genoma dos parvovirus é constituído de DNA não-segmentado, possui uma fita simples linear de aproximadamente 5.000 nucleotídeos com 4 a $6 \mathrm{~kb}$ de tamanho que codificam proteínas não-estruturais (NS1) e as proteínas estruturais (VP1 e VP2). O genoma do HBoV não codifica polimerase, assim o vírus é dependente da DNA polimerase da célula hospedeira para replicação.

Análises por microscopia eletrônica confirmaram que o HBoV apresenta as características estruturais dos membros da família Parvoviridae e possui $25 \mathrm{~nm}$ de diâmetro (figura 2).
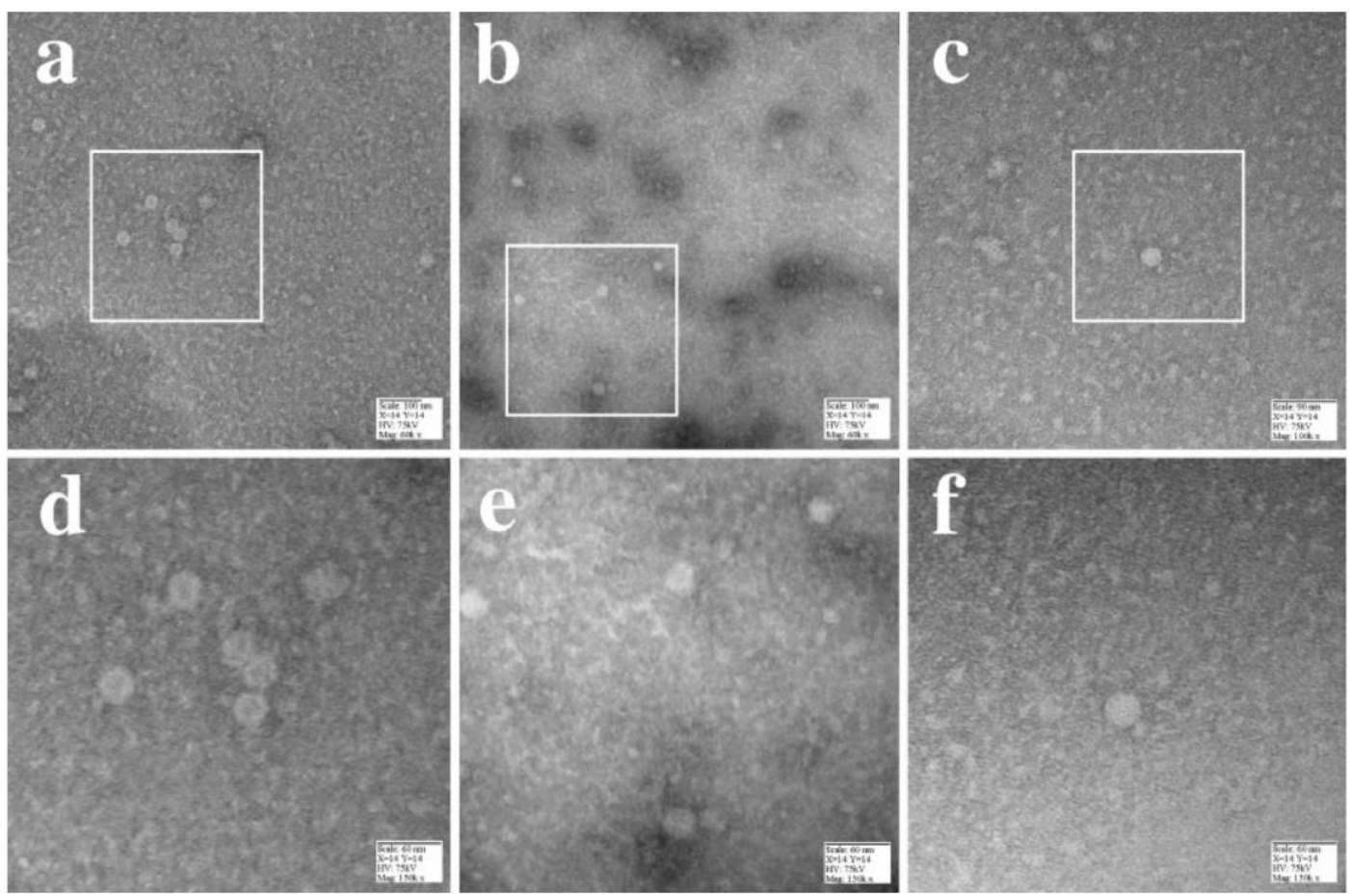

Figura 2 - Microscopia eletrônica do HBoV, diferentes ampliações 60.000 (a, b), 100.000 (c) e 150.000 (d, e, f). As caixas brancas nas micrografias a, b, c foram ampliadas nas micrografias $\mathrm{d}, \mathrm{e}, \mathrm{f}$ respectivamente. FONTE: Brieu et al. (2007).

Recentemente um estudo de crioreconstrução demonstrou que o capsídeo do HBoV possui o núcleo altamente conservado presente em todos os parvovírus, como pode ser observado na figura 3 (Gurda et al., 2010). 


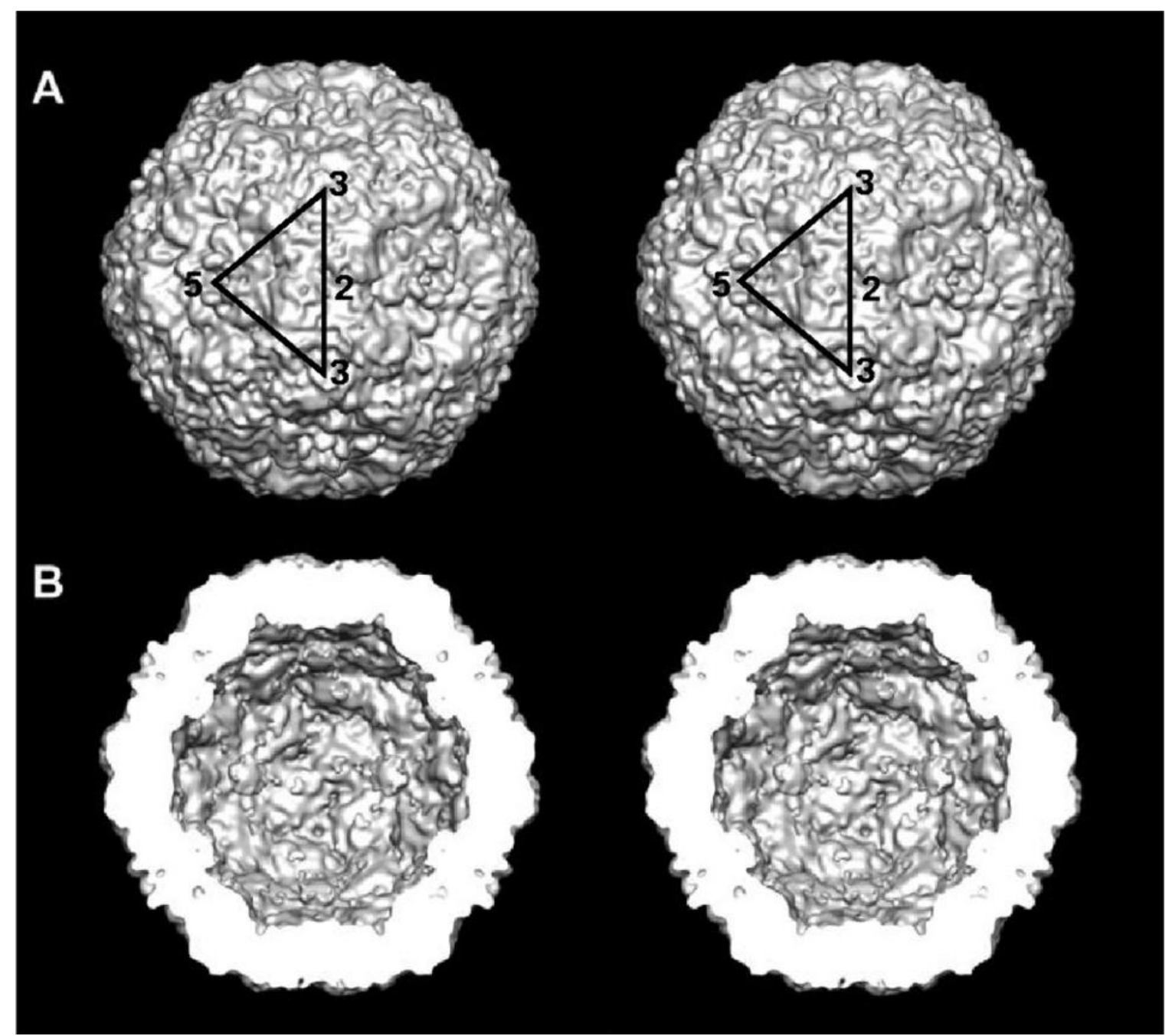

Figura 3 - Crioreconstrução do HBoV. (A) Representação sombreada da superfície do capsídeo inteiro. (B) Mesma estrutura do painel A com a metade frontal removida gerando uma vista em perspectiva.

FONTE: Gurda et al. (2010).

A conservação dos principais aspectos estruturais dos parvovírus é coerente com as funções essenciais de montagem e estabilidade do capsídeo. De maneira geral, o HBoV partilha a maioria das características de superfície do capsideo com os demais parvovírus humanos, o B19 e o vírus adeno associado 2 (AAV2), o que resulta em uma morfologia de capsídeo única como pode-se observar na figura 4 (Gurda et al., 2010). 


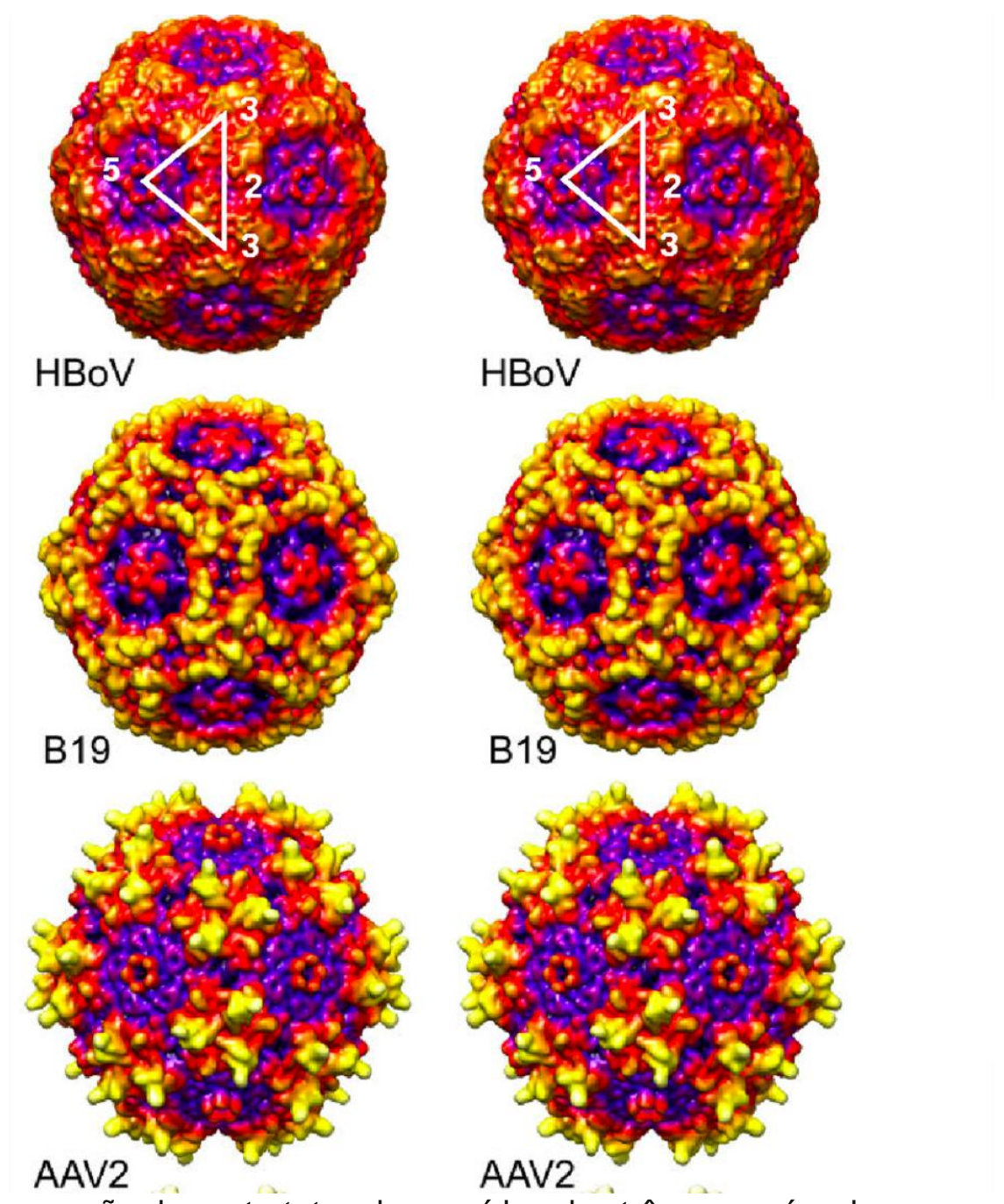

Figura 4 - Comparação das estrututas do capsídeo dos três parvovírus humanos FONTE: Gurda et al. (2010).

\subsection{Organização genômica}

A organização do genoma do gênero Bocavirus (figura 5), como em todos os membros da subfamília Parvovirinae, possui duas ORFs principais codificando uma proteína não-estrutural (NS1) e ao menos duas proteínas de capsídio (VP1 e VP2). A função da proteína NS1 do HBoV é desconhecida, porém especula-se que estaria envolvida na replicação do DNA (Zhi et al., 2006). Contudo, como o MVC e o BPV, o HBoV também possui uma terceira ORF entre as duas principais, esta ORF codifica uma proteína não estrutural de função desconhecida, chamada NP-1. A comparação do produto da ORF central do $\mathrm{HBoV}$ com as dos outros dois vírus do gênero mostrou $47 \%$ de homologia, reforçando a classificação do HBoV como Bocavirus, a 
árvore filogenética (figura 6) nos mostra a posição dos isolados em relação aos outros parvovirinae (Allander et al., 2005).

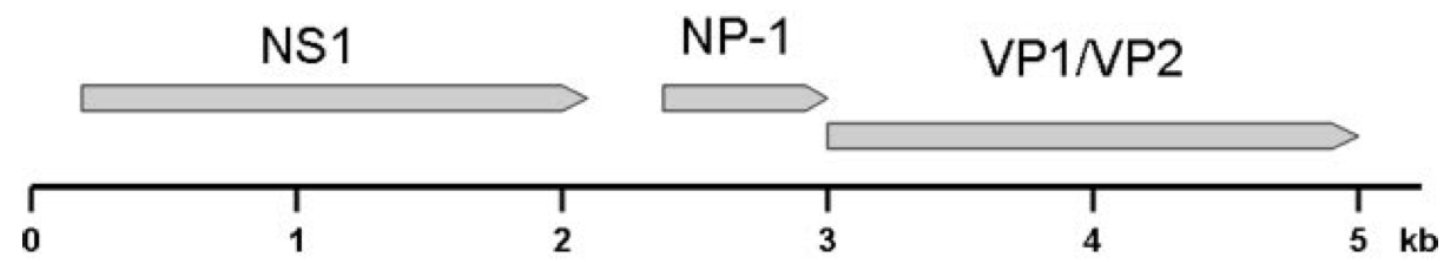

Figura 5 - Mapa genomico do HBoV. (A) Mapa esquemático do isolado ST1 mostrando as três ORFs: NS1 contem 1.920 nt (183 ao 2.102 nt), os quais codificam 639 aa; NP-1 contem 660 nt (2.340 ao 2.999), os quais codificam 219 aa; e VP1/VP2 contem 2.016 nt (2.986 ao 5.001), os quais codificam 671aa.

FONTE: Allander et al. (2005).

Genoma Completo (nucleotídeos)

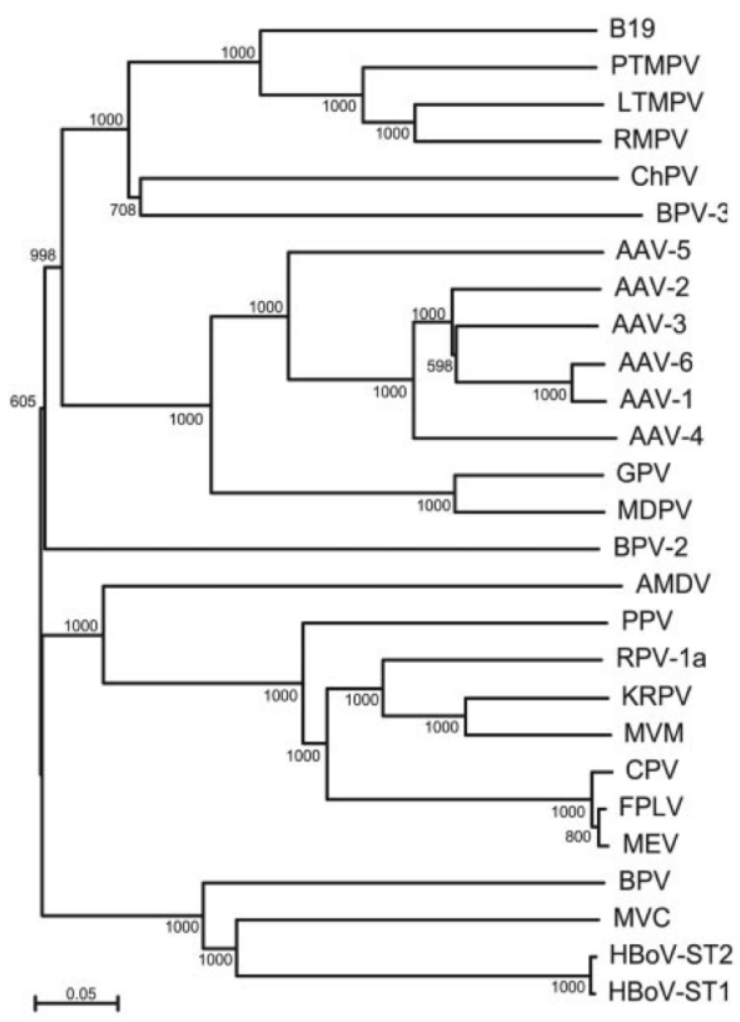

ORF 1 (proteína)

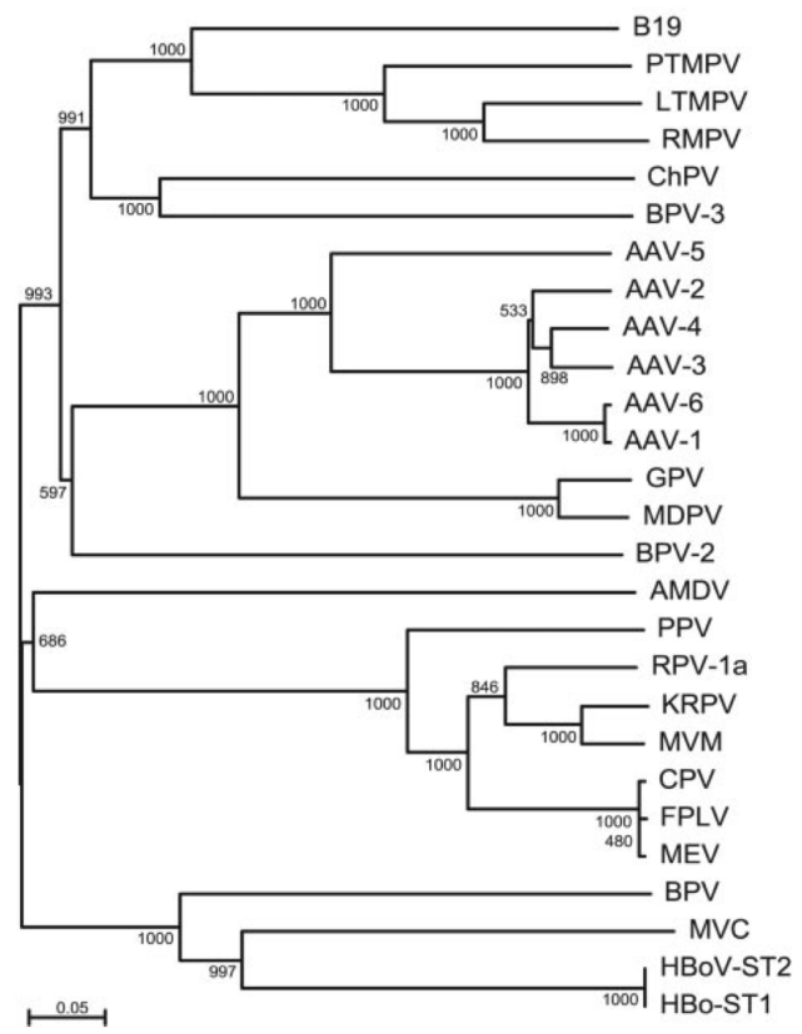

Figura 6 - Topologia da arvore obtida pelo método de neighbor-joining com valores de bootstrapped em seus ramos. Baseadas na sequência completa de nucleotídeos com os Parvovirinae.

FONTE: Allander et al. (2005).

Nos Estados Unidos, foi relatado que a maior taxa de polimorfismo de nucleotídeos ocorre nos genes VP1/VP2. A seqüência de nucleotídeos dos vírus de 
um dos genótipos encontrados era quase idêntica a do ST1, e o segundo genótipo era quase idêntico ao ST2 (Kesebir et al., 2006). Em estudos no Canadá (Bastien et al., 2007) e na Alemanha (Neske et al., 2007) também foram identificados dois genótipos (figura 7).

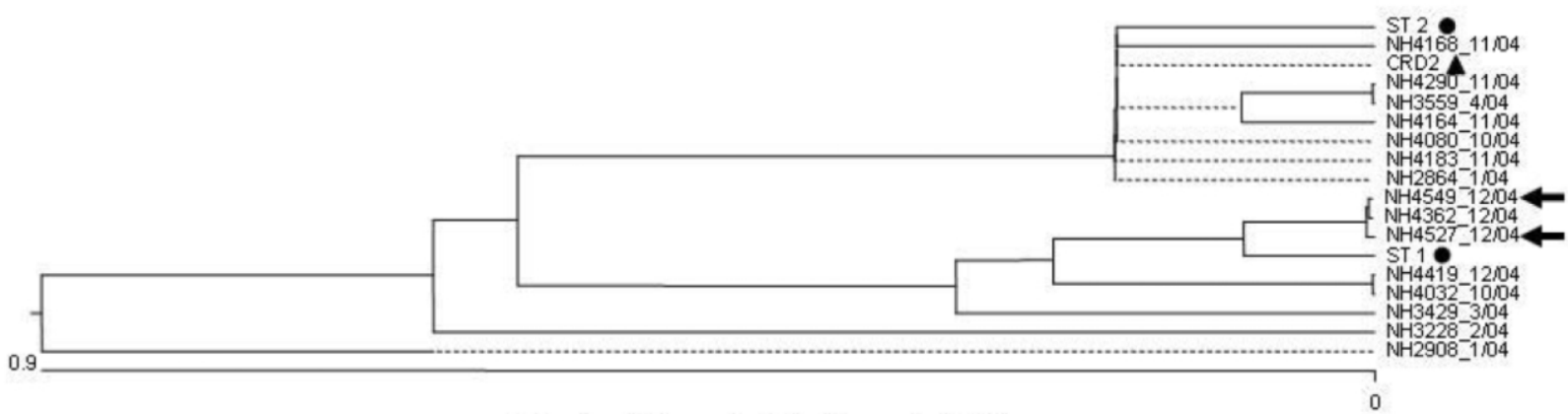

Figura 7 - Análise filogenética dos isolados do HBoV encontraddos nos Estados Unidos. Legenda: • As cepas inicias de HBoV (ST1 e ST2) identificadas por Allander et al (2005)]; $\Delta$ e setas: isolados de HBoV norte-americanas.

FONTE: Kesebir et al. (2006).

Chieochansin et al. (2007) seqüenciaram o genoma completo do HBoV utilizando primers de regiões conservadas. As amostras foram obtidas de aspirados de nasofaringe de crianças, com idades entre um mês e nove anos, admitidas com doença respiratória no hospital da Universidade Shulalongkorn na Tailândia em 2006. Dezoito amostras, de um total de 252 , foram positivas para HBoV $(7,14 \%)$, as amostras designadas como CU6, CU49 e CU74 foram seqüenciadas. Os produtos amplificados, 5301 pares de bases, dos três isolados traduzem as proteínas não estrutural NS1, NP1 e as proteínas de capsídeo VP1 e VP2 contendo 639, 219, 671 e 542 aminoácidos respectivamente. A maioria das mutações apareceram no gene VP1/VP2 já os genes NS1 e NP1 são as regiões mais conservadas.

A análise da seqüência completa do HBoV mostra que as variações de nucleotideos nas regiões VP1 e VP2 dividem os bocavirus em dois e três grupos, respectivamente. Na Tailândia o $\mathrm{HBoV}$ de todos os grupos foram detectados, mostrando que a variação independe da localização geográfica. Esse estudo indicou que apesar do HBoV ser um vírus conservado, suas quase uniformes variações aparecem nos genes da proteína de capsídeo (VP1/VP2). Os genes NS1 e NP1 são as regiões mais conservadas e podem ser utilizadas para detecção e diagnóstico do HBoV (Chieochansin et al., 2007). 


\subsection{Epidemiologia}

O HBoV foi detectado ao redor do mundo, desde a sua descoberta na Suécia (Allander et al., 2005) e posteriormente na Inglaterra (Manning et al., 2006), Alemanha (Weissbrich et al., 2006), Canadá (Bastien et al., 2006), EUA (Kesebir et al., 2006), Austrália (Sloots et al., 2006), África do Sul (Smults et al., 2006), Jordânia (Kaplan et al., 2006), Japão (Ma et al., 2006), Korea (Choi et al., 2006), Tailândia (Fry et al., 2007), China (Qu et al., 2007), Finlandia (Monteny et al., 2007), Suíça (Regamey et al., 2007) e no Brasil, em amostras fecais (Albuquerque et al., 2007) e respiratórias (Gagliardi et al., 2009), entre outros países. A maioria dos estudos foi realizada em amostras de secreção do trato respiratório e alguns em fezes de pacientes, sendo a maior parte das crianças com ITR. Os estudos mostraram taxas de prevalência que variaram de 1,5\% a $19 \%$.

$\mathrm{O} \mathrm{HBoV}$ é detectado frequentemente em crianças com menos de 2 anos de idade (Allander et al., 2005) e alguns estudos mostram uma incidência menor em bebes com menos de 6 meses de idade (Foulongne et al., 2006; Ma et al., 2006), ou seja, sua incidência aumenta quando diminui a quantidade de anticorpos maternos, o que sugere que o $\mathrm{HBoV}$ é um vírus endêmico com altas taxas de contágio em crianças susceptíveis. A prevalência do HBoV diminui com o aumento da idade do paciente e é raramente detectado em adultos (Bastien et al., 2006; Kupfer et al., 2006; Manning et al., 2006; Fry et al 2007).

\subsection{Distribuição Sazonal}

Diferentes estudos relatam a sazonalidade do HBoV, (Weissbrich et al., 2006; Kesebir et al., 2006; Bastien et al., 2006; Manning et al., 2006; Maggi et al., 2007; Naghipour et al., 2007; Allander et al., 2007; Fry et al., 2007; Neske et al., 2007), porém a analise em conjunto não indica ocorrência sazonal regular na infecção por este vírus e não levam em conta a possibilidade da presença assintomática o que alteraria as estimativas de prevalência. Diversos estudos são de regiões de climas temperados e relatam ocorrência maior durante o inverno e a primavera (Allander et al., 2005). Na Koreia a ocorrência relatada é maior no final da primavera e começo do verão (Choi et al., 2006). Por outro lado, Casos de crianças internadas com 
chiado e sintomas primários de infecção por HBoV foram detectados ao longo de todo o ano (Allander et al., 2007). Para a determinação da sazonalidade são necessários mais estudos retrospectivos.

No Brasil, em Ribeirão Preto, um estudo estabeleceu um padrão sazonal para a ocorrência do HBoV, sendo um pico observado no outono, como ilustrado pela figura 8.

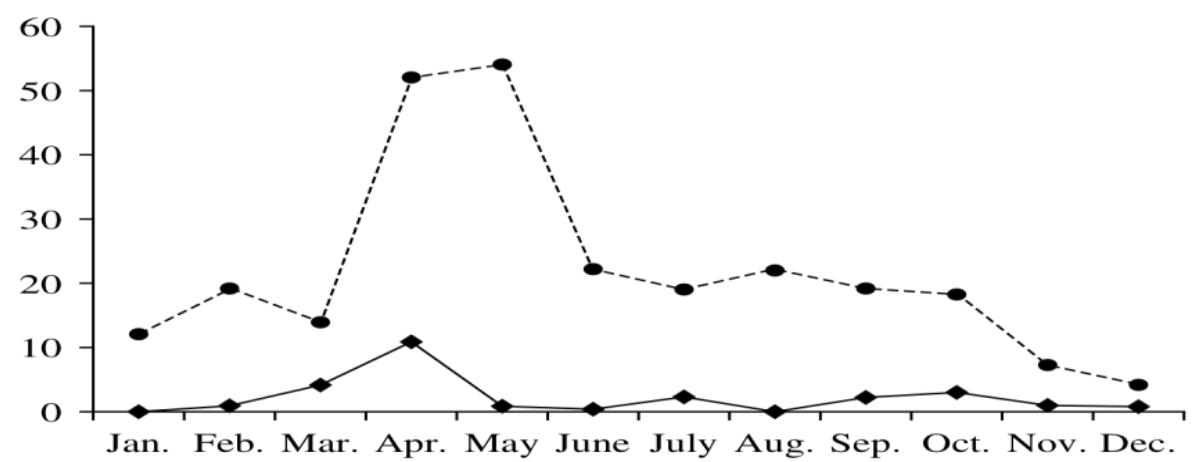

Figura 8 - Sazonalidade reportada em Ribeirão Preto - SP. Legenda: $\bullet-$ Amostras positivas para $\mathrm{HBoV}$; $\bullet-\bullet$ Todas as amostras.

FONTE: Gagliardi et al. (2009).

\subsection{Manifestações Clinicas}

O HBoV é frequentemente encontrado em coinfecções com outros vírus o que dificulta estudos sobre sua patogenicidade. Os Postulados de Koch (1. A presença do agente deve ser sempre comprovada em todos os indivíduos que sofram da doença e, a partir daí, isolada em cultura pura; 2. O agente não poderá ser encontrado em casos de outras doenças; 3. Uma vez isolado, o agente deve ser capaz de reproduzir a doença, após a sua inoculação em animais experimentais; 4. O mesmo agente deve poder ser recuperado desses animais experimentalmente infectados e de novo isolado em cultura pura) não podem ser aplicados na ausência de cultura in vitro e de modelos animais, assim sendo deve-se aplicar o critério de causalidade desenvolvido para diagnóstico molecular de Friedricks e Relman (1996). Estudos recentes mostram que HBoV supre muitos desses critérios, porém alguns ainda não foram testados (Allander et al., 2008). 


\subsubsection{Infecções Respiratórias}

Muitos estudos levantam a possibilidade do HBoV estar relacionado com infecção respiratoria aguda, estes estudos encontraram o vírus em crianças hospitalizadas com bronquiolite (Jacques et al., 2008), ataques de asma (Allander et al., 2007; Gendrel et al., 2007) e chiados (Bosis et al., 2008), sendo mais freqüentemente encontrado em pacientes com sintomas respiratórios do que em pacientes assintomáticos (Kesebir et al., 2006; Allander et al., 2007; Fry et al., 2007; Maggi et al., 2007).

Um estudo na Jordânia mostrou que $18 \%$ das crianças hospitalizadas com pneumonia foram positivas para HBoV (Kaplan et al., 2006). Na Tailândia foi relatado que pacientes que tiveram $\mathrm{HBoV}$ eram mais prováveis ser hospitalizados com pneumonia em comparação com os controles (Fry et al., 2007).

A maioria dos artigos sobre o HBoV são análises retrospectivas baseadas em ambientes hospitalares. Nesses estudos mais de 6\% dos pacientes requer internação em UTI e mais de $40 \%$ necessitam de oxigenoterapia. Estes estudos provavelmente superestimam a gravidade da doença associada com HBoV-1 devido a curva de seleção. Em estudos com base em amostras da comunidade, a doença é leve e só raramente exige internação. Até a presente data, não houve nenhuma morte relatada associada com HBoV (Chow et al., 2008; Arnald et al., 2006).

Em um estudo retrospectivo com crianças asmáticas o HBoV foi detectado em $13 \%$ dos pacientes internados com ataque de asma severo e apenas em $2 \%$ dos pacientes ambulatoriais com asma estável. O que sugere a relação do HBoV como uma possível causa da exacerbação da asma em crianças (Vallet et al., 2009).

\subsubsection{Infecções gastrointestinais}

Além de estar associado a sintomas do trato respiratório inferior e superior o HBoV também foi encontrado no trato gastrointestinal de pacientes com gastroenterite com ou sem sintomas respiratórios (Vicente et al., 2007). Arnald et al. em 2006 relataram que $16 \%$ dos casos positivos para HBoV em um hospital infantil apresentavam diarréia. Na Alemanha, de 31 pacientes positivos para HBoV no trato respiratório, $45 \%$ das amostras fecais eram positivas para HBoV. Arthur et al., (2009) encontraram o HBoV, bem como HBoV-2 e HBoV-3, em amostras de pacientes internados com gastroenterite aguda. 
O HBoV apesar de raramente ser detectado em adultos, pode ser encontrado em pacientes imunodeprimidos (Kupfer et al., 2006; Bastien et al., 2006; Manning et al., 2006).

\subsection{Coinfecção}

A coinfecção do HBoV com outros patógenos é frequente. Em estudos realizados na Universidade de Bonn, na Alemanha, a freqüência de coinfecção foi de $36 \%$ (Schildgen et al., 2008), outros estudos mostram uma taxa de coinfecção variando de 18\% a 90\% (Allander et al., 2005; Fry et al., 2007).

Vicente et al. (2007) ao estudar 40 amostras do trato respiratório positivas para HBoV, encontraram 25 amostras (62,5\%) coinfectadas com vírus respiratório sincicial (RSV), rhinovírus (RhV), influenza $A(I A)$, coronavírus (CoV), adenovírus (HAdV), influenza B (IB). Em 48 amostras fecais positivas para HBoV, 28 (58,3\%) apresentavam coinfecção com outro patógeno intestinal (Salmonella enteritidis) Campylobacter jejuni, rotavírus, norovírus, C. jejuni e norovírus.

Uma das hipóteses apresentadas para explicar essas altas taxas de coinfecção é que o HBoV está envolvido na patogênese e, de alguma maneira agravaria os sintomas como ocorre com pacientes com asma (Vallet et al., 2009), a terceira possibilidade é que o $\mathrm{HBoV}$ seria um vírus que ajuda outros vírus, ou mesmo necessitaria da ajuda de outros para ativação ou reativação de sua replicação (Schildgen et al., 2008), seja como for mais informações a respeito são necessárias para que o modelo de seu mecanismo de ação seja estabelecido.

\subsection{Diagnóstico laboratorial}

O diagnóstico do HBoV tem sido realizado, preferencialmente, por métodos moleculares como a PCR. As amostras são, geralmente, de aspirados de nasofaringe (ANF), swabs nasais e amostras fecais quando associado a gastroenterite (Allander et al., 2007; Vicente et al., 2007; Arthur et al., 2009). A região do genoma mais utilizada para o desenho de iniciadores para analises de diagnóstico é a que codifica o gene NP1 pois, juntamente com a NS1, formam a região mais conservada do genoma. Para estudos de filogenia ou variabilidade a 
região que tem sido mais utilizada é a região VP1/VP2 que apresenta maior variabilidade (Allander et al., 2005).

Diversos estudos utilizaram com sucesso a PCR em tempo real para detecção e quantificação do HBoV. Nesses estudos altas cargas virais de HBoV são encontradas em crianças internadas com sintomas respiratórios agudos (Neske et al., 2007; Lu et al., 2006; Chi, 2008; Schenk, 2007).

O DNA do HBoV pode, ainda, ser detectado na corrente sanguínea de pacientes sintomáticos (Allander et al., 2007).

A Microscopia eletrônica se mostra um método demorado e de baixa sensibilidade para diagnósticos laboratoriais, mas pode ser usado para pesquisas sobre a estrutura do vírus (Brieu et al., 2007).

Um método sorológico foi apresentado baseado na resposta sistêmica das células $B$ ao HBoV. Pela quantidade de anticorpos HBoV-específicos é possível identificar infecções agudas causadas pelo vírus em crianças hospitalizadas com sintomas respiratórios severos (Kantola et al., 2008), porém este método deve ser associado aos métodos baseados em PCR para um diagnóstico mais fidedigno.

Em uma tentativa de aperfeiçoar os métodos de diagnóstico foram realizados imunoensaios enzimáticos de imunoglobulina ( $\mathrm{lg}$ ) $\mathrm{G}$ e $\mathrm{IgM}$ com partículas recombinates "virus-like" de $\mathrm{HBoV}$ como antígenos, os ensaios apresentaram a sensibilidade de $97 \%$ e uma especificidade de $99,5 \%$ no diagnóstico (SöderlundVenermo et al., 2009).

Até o presente momento, não há métodos de cultura de HBoV in vitro ou em modelos animais. 


\section{OBJETIVOS}

A presente pesquisa tem como objetivo principal verificar a variabilidade genética de bocavirus humano, detectados em amostras de aspirados de nasofaringe de crianças de até dois anos de idade internadas no HSCM-SP com doença respiratória aguda.

E como objetivos secundários:

1) Verificar a ocorrência do HBoV em amostras de ANF de crianças internadas no HSCM-SP com doença respiratoria aguda

2) Verificar a ocorrência de HBoV associado a outros vírus respiratórios.

3) Determinar a sazonalidade do HBoV no período compreendido entre fevereiro de 2008 a fevereiro de 2010.

4) Caracterizar molecularmente o perfil das amostras de HBoV comparando-as com amostras do GeneBank.

5) Análise de variabilidade genética inter e intragrupo das cepas brasileiras de HBoV. 


\section{MATERIAL E MÉTODOS}

\subsection{Casuística}

Trata-se de um estudo retrospectivo realizado com 985 amostras de ANF provenientes de pacientes de 0 a 24 meses de idade, internados no departamento de Pediatria do Hospital da Santa Casa de Misericórdia de São Paulo com sintomas respiratórios agudos do trato respiratório inferior. A coleta das amostras foi realizada entre fevereiro de 2008 e fevereiro de 2010. Tais amostras e respectivas espécimes clínicas, fazem parte da coleção (Teca) sob a responsabilidade do Prof. Dr. Edison L. Durigon.

O projeto utilizou material biológico armazenado, obtido de seres humanos mas que, após processamento, consiste, basicamente, de material genético. Devido a isso, a comissão de Ética em Pesquisa com Seres Humanos do ICB considerou o projeto isento, conforme parecer 937/CEP.

\subsection{Diagnóstico Laboratorial da Infecção por HBoV e Análise Genética das Estirpes.}

\subsubsection{Primers}

A seqüência-alvo, para diagnóstico e posterior seqüenciamento do $\mathrm{HBoV}$ está apresentada na tabela abaixo.

Tabela 03 - Relação dos primers utilizados no seqüenciamento de HBoV pela técnica de PCR.

\begin{tabular}{|c|c|c|c|c|c|}
\hline Primer & $\begin{array}{l}\text { Posição } \\
\text { (gene) }\end{array}$ & Seqüência & $\begin{array}{l}\text { Tamanho } \\
\text { do } \\
\text { amplicon }\end{array}$ & & Ref \\
\hline HBoVf1 & $\begin{array}{l}4128-4149 \\
\text { (VP1/VP2) }\end{array}$ & 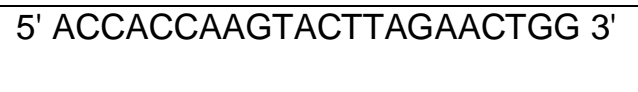 & & PCR & $\begin{array}{c}\text { Desenhado } \\
\text { no }\end{array}$ \\
\hline HBoVr1 & $\begin{array}{l}4785-4765 \\
\text { (VP1/VP2) }\end{array}$ & 3' AATAGTGCCTGGAGGATGATCC 5' & $657 \mathrm{pb}$ & Seq & Laboratório \\
\hline
\end{tabular}

* utilizado a amostra ST1 do genebank, como consenso.

\subsubsection{Extração do DNA total}

A extração do material genético viral, cerca de $200 \mu$, foi feita com a utilização do Nuclisens ${ }^{\circledR}$ Iso Kit (BioMerieux, Lyon, France) com o protocolo on-board, conforme instruções do fabricante. 


\subsubsection{PCR para detecção do HBoV}

A reação de PCR foi realizada utilizando o DNA obtido logo após o processo de extração. A amplificação foi efetuada com a diluição de $10 \mu \mathrm{l}$ de DNA em tampão $20 \mathrm{mM}$ de Tris- $\mathrm{HCl}$ [pH 8.4]. $50 \mathrm{mM}$ de $\mathrm{KCl}, 2 \mathrm{mM}$ de $\mathrm{MgCl}_{2}, 12,5$ pMoles de cada primer, 1,5 U de Taq DNA Polimerase (Biotools), $0.2 \mathrm{mM}$ de dNTP e água UltraPure $\left(\right.$ Gibco $^{\circledR}$ ) para um volume final de $50 \mu \mathrm{L}$. As amostras foram amplificadas em termociclador automático (GeneAmp PCR System 9700, Applied Biosystems Inc., EUA), a partir de uma etapa a $95{ }^{\circ} \mathrm{C}$ por $5 \mathrm{~min}$, seguida de 35 ciclos a $94{ }^{\circ} \mathrm{C}$ por 45 segundos para desnaturação das fitas; $56{ }^{\circ} \mathrm{C}$ por 45 seg para o anelamento dos primers e $72{ }^{\circ} \mathrm{C}$ por 1 min para extensão seguida de uma etapa final de $72{ }^{\circ} \mathrm{C}$ por 7 min para completar a extensão. Os produtos amplificados foram estocados a $4{ }^{\circ} \mathrm{C}$ até o próximo procedimento.

\subsubsection{Análise dos produtos amplificados}

A detecção do produto amplificado foi realizado por eletroforese em gel de agarose (Gibco BRL ${ }^{\circledR}$ ) a 2\% em tampão TBE 1x (45 mM de Tris-Borato, $1 \mathrm{mM}$ de EDTA [pH 8.0]) e $0,5 \mu \mathrm{g} / \mathrm{ml}$ brometo de etídeo. Uma aliquota de $10 \mu \mathrm{l}$ da amostra misturados com $2 \mu \mathrm{l}$ de azul de bromofenol (loadding buffer) foi submetida à eletroforese em cuba horizontal (Gibco $B L^{\circledR}$ ), imerso em tampão TBE (1x concentrado) durante 40 minutos a $100 \mathrm{~V}$. A visualização do gel foi realizada em transiluminador de luz ultravioleta (MacroVue UV-20 HOEFER).

\subsubsection{Purificacão dos produtos amplificados}

O produto amplificado foi purificado utilizando ExoSAP-IT (exonuclease I Amersham Pharmacia Biotech) na proporção de 1:2,5 (2ul de enzima em 5ul de PCR) como instrução dos fabricante. O produto purificado foi submetido à eletroforese em gel de agarose a $2 \%$ como descrito no item 3.2.5 para a quantificação das bandas, com auxílio de marcador de peso molecular (DNA Mass Ladder - BIOTOOLS). 


\subsubsection{Seqüenciamento do Gene VP1/VP2}

Após a purificação, as fitas de DNA foram seqüenciadas utilizando-se o kit ABI PRISM Dye TM Terminator Cycle Sequencing Ready Reaction kit (Big Dye Applied Biosystems, Inc., EUA), seguindo as instruções do fabricante.

Foram utilizados para o seqüenciamento das cepas, os primer descritos na tabela 3. Cerca de $5 \mu \mathrm{l}$, correspondendo entre 10 e $30 \mathrm{ng}$ do produto purificado, foram adicionados a um microtubo contendo $3,2 \mathrm{pmol}$ de primer sense ou antisense, $2 \mu \mathrm{l}$ do Terminator ready reaction Mix (Big Dye) e $2 \mu \mathrm{l}$ do tampão de seqüenciamento (save money - Tris $\mathrm{HCl} 200 \mathrm{mM}[\mathrm{pH} 9,0]$ e $5 \mathrm{mM} \mathrm{MgCl}_{2}$ ) além de água Milli- $Q^{\circledR}$ para completar um volume final de $10 \mu \mathrm{l}$. Todas as reações foram feitas em duplicatas, sendo uma reação de seqüenciamento com primer forward e outra com o primer reverse. Quando necessário uma nova reação com um dos primers foi realizada.

A extensão enzimática foi realizada em termociclador GeneAmp PCR System 2400 durante $96{ }^{\circ} \mathrm{C} / 1 \mathrm{~min}$. seguido de 25 ciclos de $96{ }^{\circ} \mathrm{C}$ por 10 segundos para a desnaturação do DNA molde, $50^{\circ} \mathrm{C}$ por 10 segundos para o annealing dos primers e $60{ }^{\circ} \mathrm{C}$ por 4 minutos para a extensão. $\mathrm{O}$ produto obtido foi purificado, visando à remoção de excesso de dideoxinucleotídeos e primers presentes na reação, com o KIT X-Terminator (Applied Biosystems Inc., EUA) conforme instruções do fabricante. Em $10 \mu \mathrm{l}$ da reação de seqüenciamento foi acrescido $10 \mu \mathrm{l}$ do X-Terminator e $60 \mu \mathrm{l}$ de tampão da reação (SAM'S). O mix foi agitado por 30 minutos seguido de uma centrifugação a 1000x g por 1 minutos e submetidos à eletroforese em polímero POP6, utilizando seqüenciador automático ABI modelo 310 (Applied Biosystems, Inc., EUA).

\subsubsection{Processamento e alinhamento das seqüências do gene VP1/VP2}

As sequência de nucleotídeos foram analisadas e editadas com o programa SeqMan e, posteriormente, foram alinhadas utilizando o programa Meg $\operatorname{Align}^{\mathrm{TM}} 4.05$, ambos do pacote Expert Analysis Software (DNASTAR, Inc., EUA), obtendo como resultado o grau de similaridade entre as seqüências, calculadas par a par, o que possibilitou a identificação de seqüências de nucleotídeos idênticas.

Com 0 intuito de otimizar as análises subseqüentes, escolheu-se aleatoriamente, apenas uma amostra de cada grupo de seqüências idênticas. Desta 
forma seqüências que apresentarem pelo menos uma mudança no número ou posição dos nucleotídeos, foram submetidas à análise filogenética.

\subsubsection{Genotipagem do Bocavírus humano}

Com a finalidade de genotipar, as amostras brasileiras foram comparadas com seqüências de HBoV, HBoV-2, HBoV-3 e HBoV-4 previamente publicadas no GenBank e alinhadas pelo método Clustal W para obtenção da topologia da árvore e grau de similaridade. 


\section{RESULTADOS}

\subsection{Ocorrência de Virus Respiratórios}

Foram coletadas 985 amostras de ANF de crianças com ITR, entre os meses de fevereiro de 2008 a fevereiro de 2010. Destas, $215(21,8 \%)$ foram positivas para RSV, 131 (13,3\%) para HAdV, 57 (5,8\%) para P3, 50 (5,1\%) para HMPV, 47 (4,8\%) para o HBoV, $29(2,9 \%)$ para IA sazonal, $16(1,6 \%)$ para IA/H1N1, $12(1,2 \%)$ para $\mathrm{P} 1,10(1 \%)$ para IB, $6(0,6 \%)$ para P2. Das 47 amostras positivas para HBoV, 45 foram sequenciadas. A ocorrência dos principais virus respiratórios no período estudado está demonstrada na figura 9.

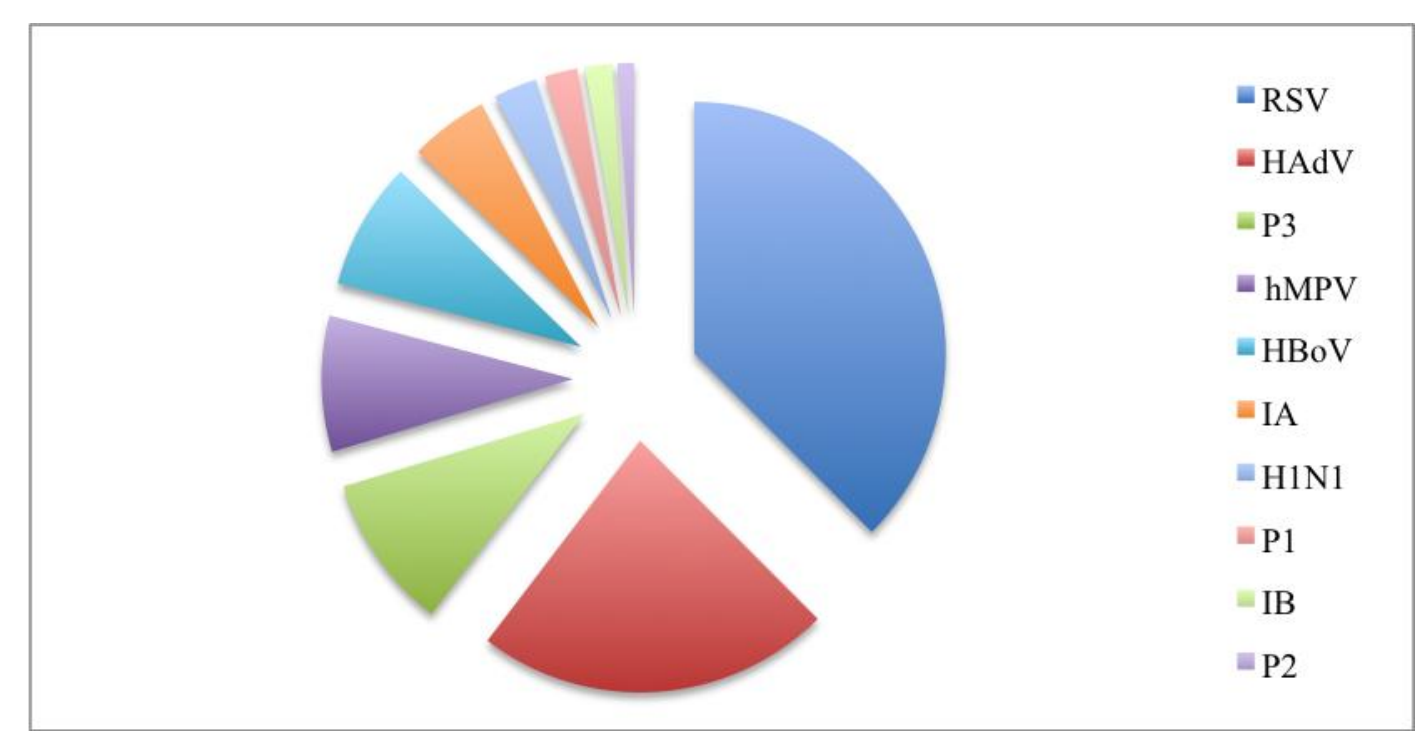

Figura 9 - Ocorrência dos principais vírus respiratórios no período de 2 anos consecutivos em crianças de até dois anos de idade, internadas com ITR no HSCM-SP.

\subsection{Sazonalidade de HBoV}

A figura 10 mostra a distribuição mensal das infecções causadas por HBoV detectadas durante o período de estudo. No ano de 2008 a maior ocorrência foi no outono e inverno, com pico no mês de julho. No ano de 2009 o HBoV distribuiu-se de modo mais uniforme e com porcentuais de positividade muito inferiores aos do ano anterior. 


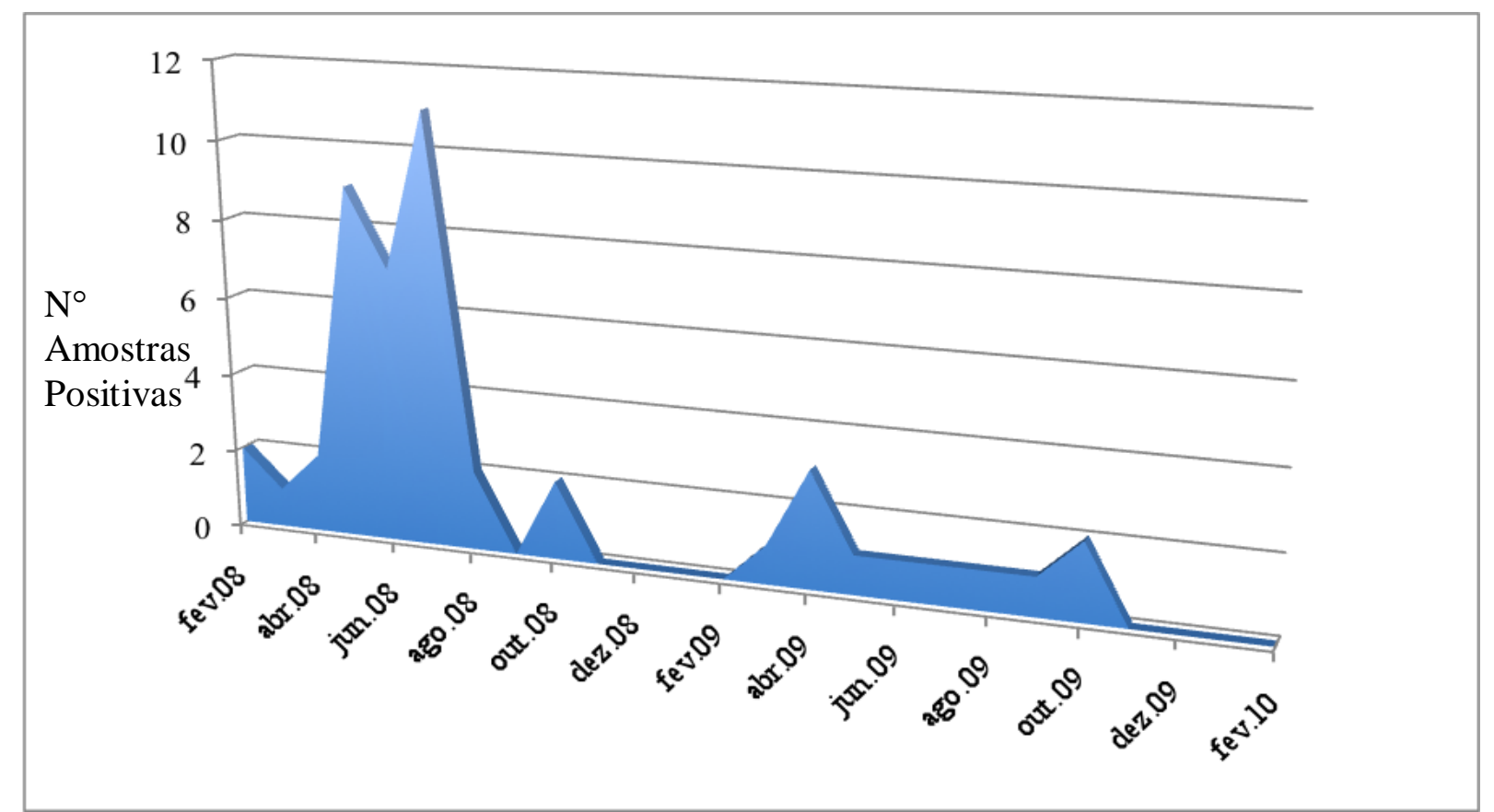

Figura 10 - Distribuição mensal das infecções causadas por HBoV em amostras de ANF provenientes de crianças menores de 2 anos de idade, internadas no HSCMSP com ITR, no período compreendido entre fevereiro de 2008 a fevereiro de 2010.

\subsection{Coinfecção}

De um total de 47 amostras positivas para o HBoV, 26 amostras (55\%) apresentaram coinfecção, sendo 18 amostras com infecção dupla, 7 amostras com infecção tripla e uma amostra com infecção quadrupla, como demonstrado nas figuras 11 e 12 . 


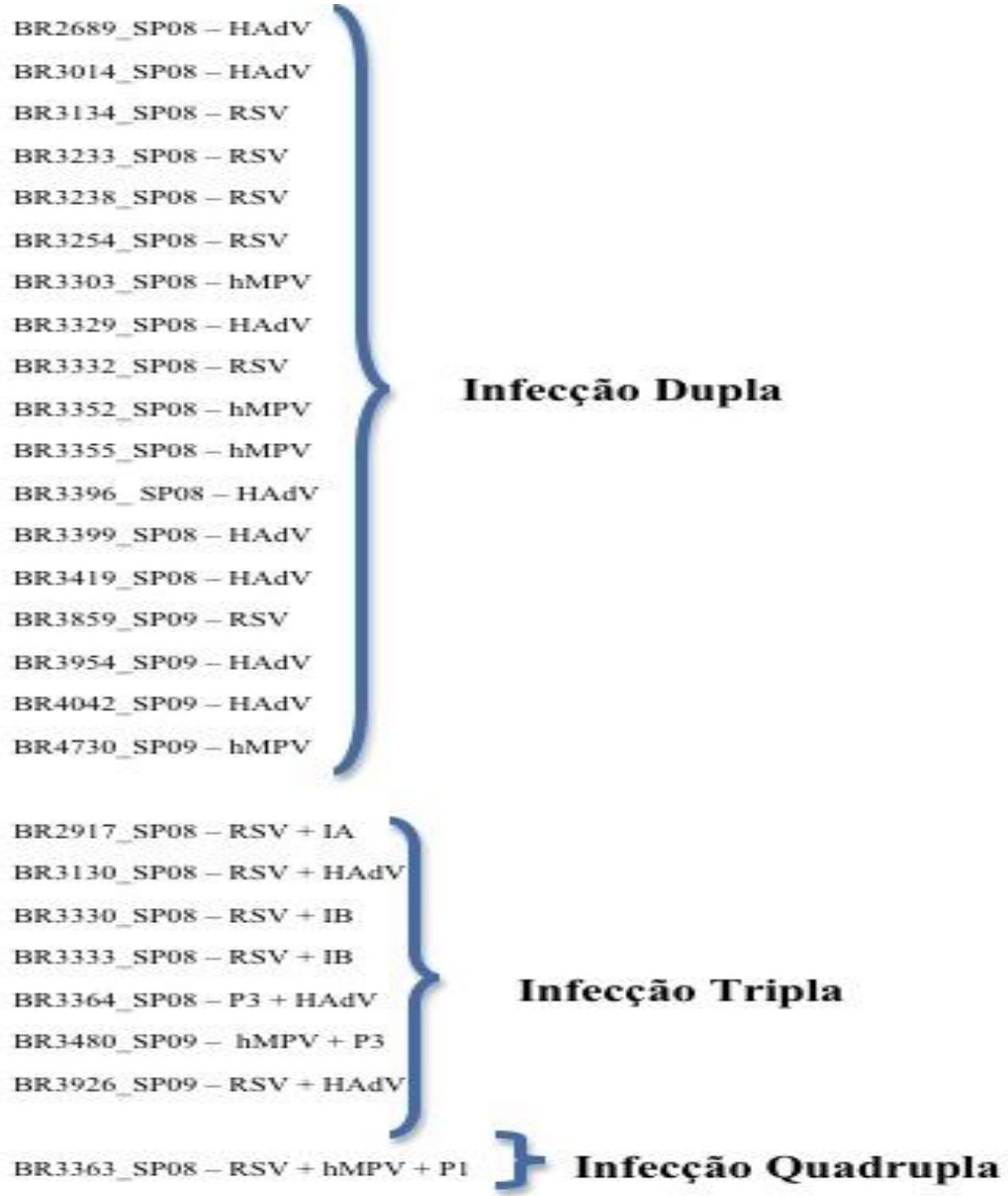

\section{Infecção Dupla}

\section{Infecção Tripla}

\section{Infecção Quadrupla}

Figura 11 - Associação do HBoV em infecções mistas detectadas em amostras de ANF provenientes de crianças menores de 2 anos de idade, internadas no HSCMSP.

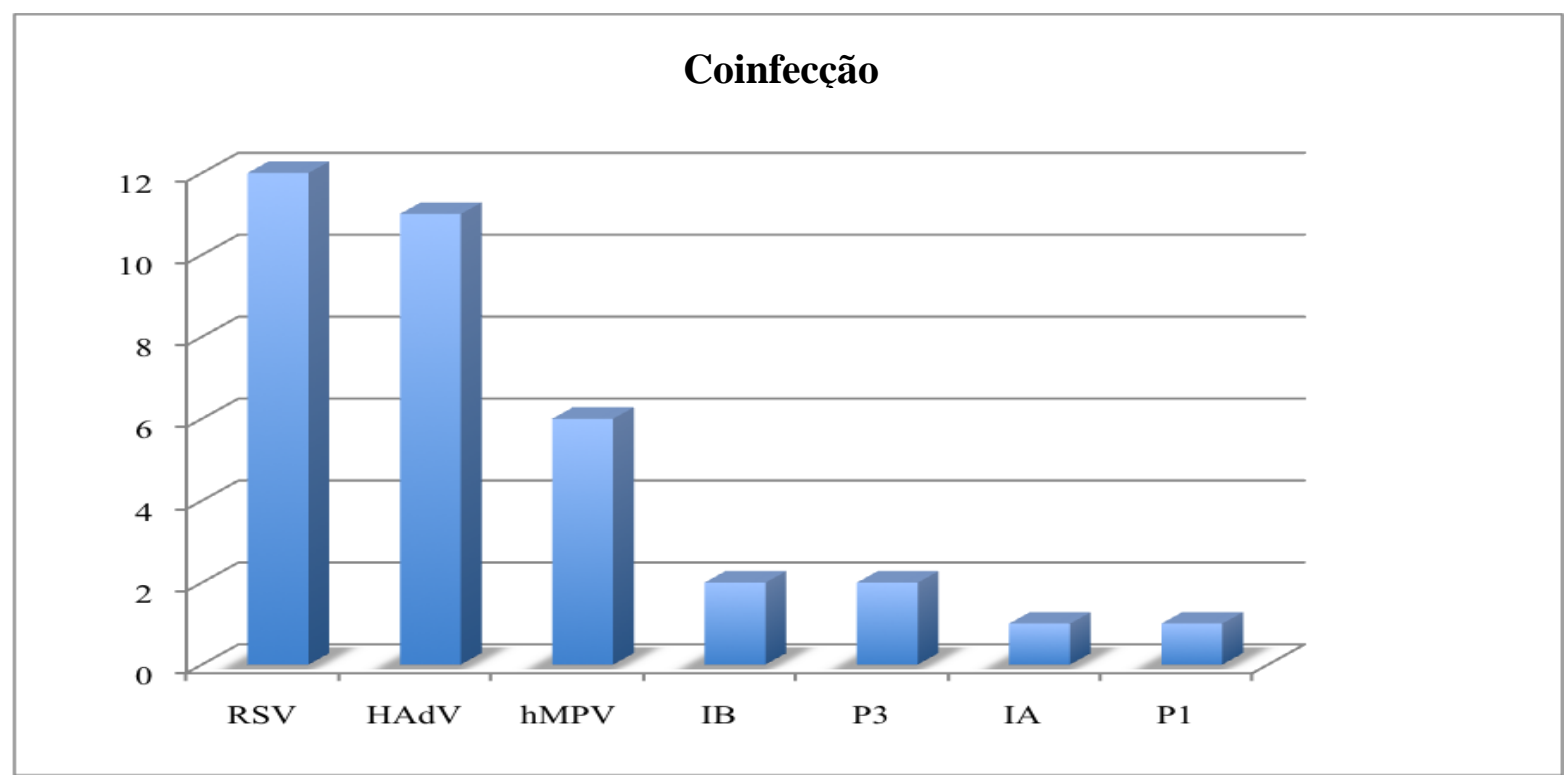

Figura 12 - Número absoluto das coinfecções de HBoV com RSV, hMPV, IA, IB, P1, P3 e HAdV em amostras de ANF provenientes de crianças menores de 2 anos de idade, internadas no HSCM-SP. 


\subsection{Genotipagem de HBoV}

A topologia da árvore obtida pelo método de Clustal W demonstrou que entre as amostras estudadas circula somente a espécie 1 do HBoV semelhantes aos encontrados no Japão, China, Tailândia e Taiwan (Figura 13)

Bootstrap

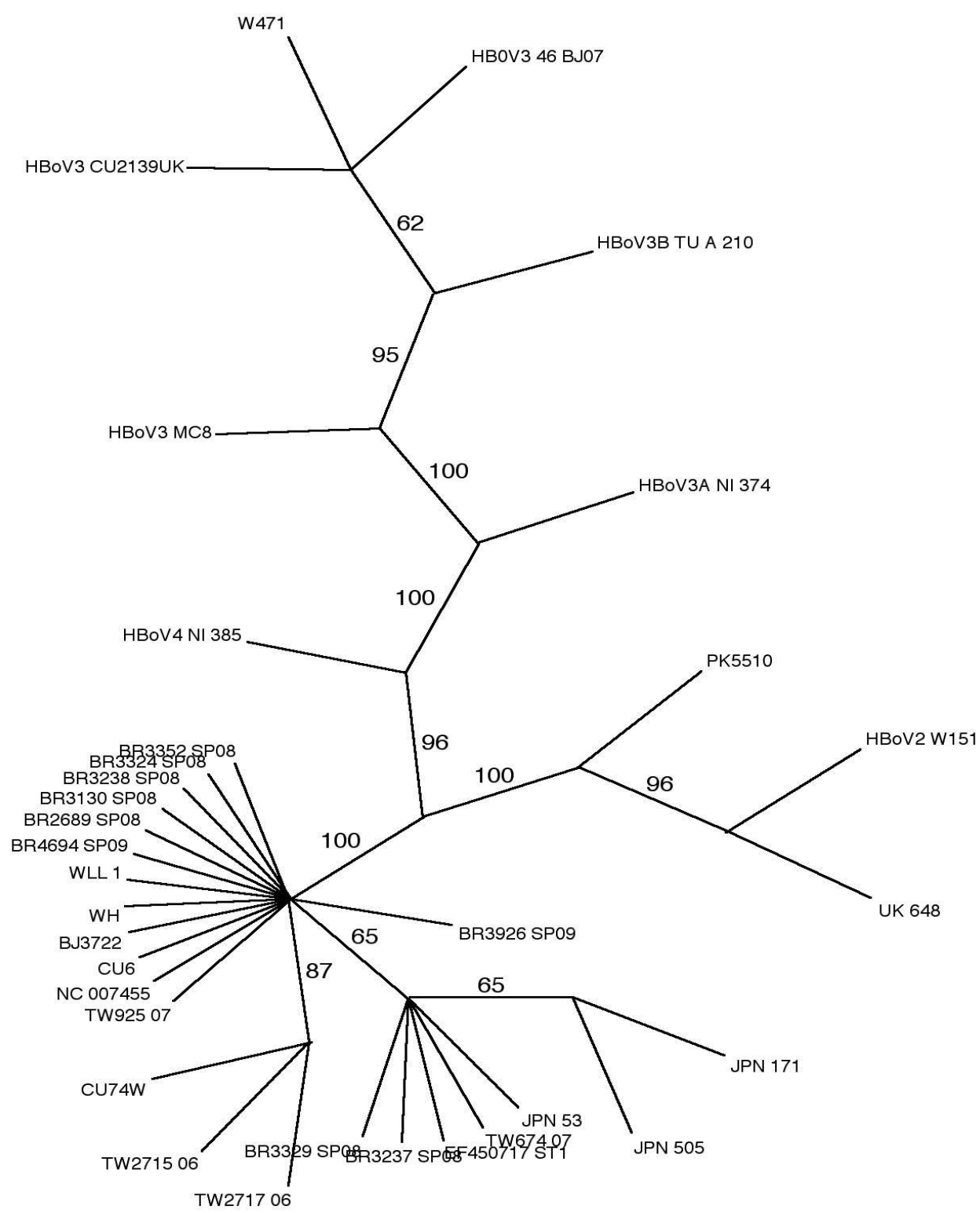

Figura 13 - Topologia da árvore obtida pelo método de Clustal W. As 24 seqüências adquiridas no GeneBank estão incluídas, identificadas pelas iniciais originais: JPN-Japão, CU-Tailândia; TW-Taiwan, ST-Suécia; BJ, WH, WLL- China, PKPaquistão, UK- Reino Unido; W-Austrália; NI-Nigéria, TU- Tunísia; e as 09 amostras brasileiras estão representadas por BR. 
As seqüências obtidas no GenBank representando o HBoV-1 eram provenientes do Japão: JPN 53 (AB480175), 171 (AB480176), 505 (AB480173); Suécia: ST1(DQ000495) e ST2 (DQ000496.1); China: BJ3722 (DQ988934), WLL-1 (DQ778300), TW674_07 (EU984244.1), TW2717_06 (EU984233), TW2715_06 (EU984232), TW925_07 (EU984245) e WH-fecal (FJ496754.1); Tailandia CU6 (ESF203920) CU74W (EU262979). Para representar o HBoV-2 foram escolhidas amostras do Paquistão PK-5510 (FJ170278.1), Austrália W151 (FJ948860) e Reino Unido UK-648 (FJ170280). Do HBoV-3 foi escolhida uma amostra australiana W471 (EU918736). Para o HBoV-3A foi escolhida uma amostra nigeriana NI07_374 (FJ973563) e para o HBoV-3B uma amostra da Tunísia TU_A210 (FJ973562). Por fim mais uma amostra da Nigéria, NI07_385 (FJ973561), representava o HBoV4.

Nas 45 amostras sequenciadas foram identificados nove conjuntos de seqüências idênticas (tabela 04).

Tabela 4 - Conjunto de amostras idênticas obtidas pelo alinhamento de nucleotídeos das seqüências brasileiras, utilizadas na análise filogenética.

\begin{tabular}{ll}
\hline Representantes & \multicolumn{1}{c}{ Conjunto de seqüências Idênticas } \\
Representadas \\
BR2689_SP08 & - \\
BR3130_SP08 & BR3134_SP08, BR3231_SP08, BR3232_SP08, \\
BR3237_SP08 & BR3298_SP08, BR3480_SP08 \\
& BR3014_SP08, BR3603_SP08, BR4042_SP09, \\
BR3238_SP08 & BR3350_SP08 \\
& BR3233_SP08, BR2917_SP08, BR3254_SP08, \\
BR3324_SP08 & BR3859_SP09 \\
BR3329_SP08 & - \\
& BR3229_SP08, BR3303_SP08, BR3330_SP08, \\
BR3352_SP08 & BR3332_SP08, BR3333_SP08, BR3369_SP08 \\
& BR3364_SP08, BR3373_SP08, BR3419_SP08, \\
& BR3443_SP08, BR3363_SP08, BR2529_SP08, \\
& BR2589_SP08, BR3355_SP08, BR3363_SP08, \\
BR3926_SP09 & BR3390_SP08, BR3954_SP09, BR4062_SP09, \\
BR4694_SP09 & BR3399_SP08, BR3636_SP08, BR3929_SP09 \\
\hline
\end{tabular}

\subsection{Análise da Variabilidade de nucleotideos inter e intra-grupo}

Com o alinhamento, pelo método de Clustal W do pacote DNAstar, entre as seqüências nucleotídicas correspondente ao intervalo de posição entre o nucleotídeo 4128 e o 4765 da região VP1/VP2 do gene codificador da proteína 
VP1/VP2 do HBoV, foi possível verificar que não houve inserções ou deleções nesta região das amostras seqüenciadas.

A análise filogenética, quando comparada com seqüência do genBank representativas de vários países, mostrou a circulação, em nossa amostragem, de grupos de HBoV-1, semelhantes aos que circulam no Japão, China, Tailandia e Taiwan. A maior similaridade genética entre as nossas amostras foi de $99,8 \%$ entre as amostras representativas: BR3130_SP08 e BR3352_SP08, BR3237_SP08 e BR3329_SP08, BR3324_SP08 e BR3352_SP08. Quando comparadas com as amostras de HBoV1 obtidas do genBank observamos a maior similaridade de $100 \%$ entre as amostras BR3237_SP08 com a ST1 e BR3352_SP08 com a BJ3722, respectivamente. Quando nossas amostras foram comparadas com o HBoV2 a maior similaridade foi de 79,1\% entre a BR3130_SP08 e a W151. Ao compararmos com o HBoV-3 a maior similaridade foi de 76,8\% entre as amostras BR3324_SP08 e NI07_374. A Comparação com o HBoV4 revelou uma similaridade de $73,9 \%$ das amostras representativas BR3238_SP08, BR3352_SP08 e BR3130S_SP08 com a amostra NI07_385, como mostrado na figura 14. 


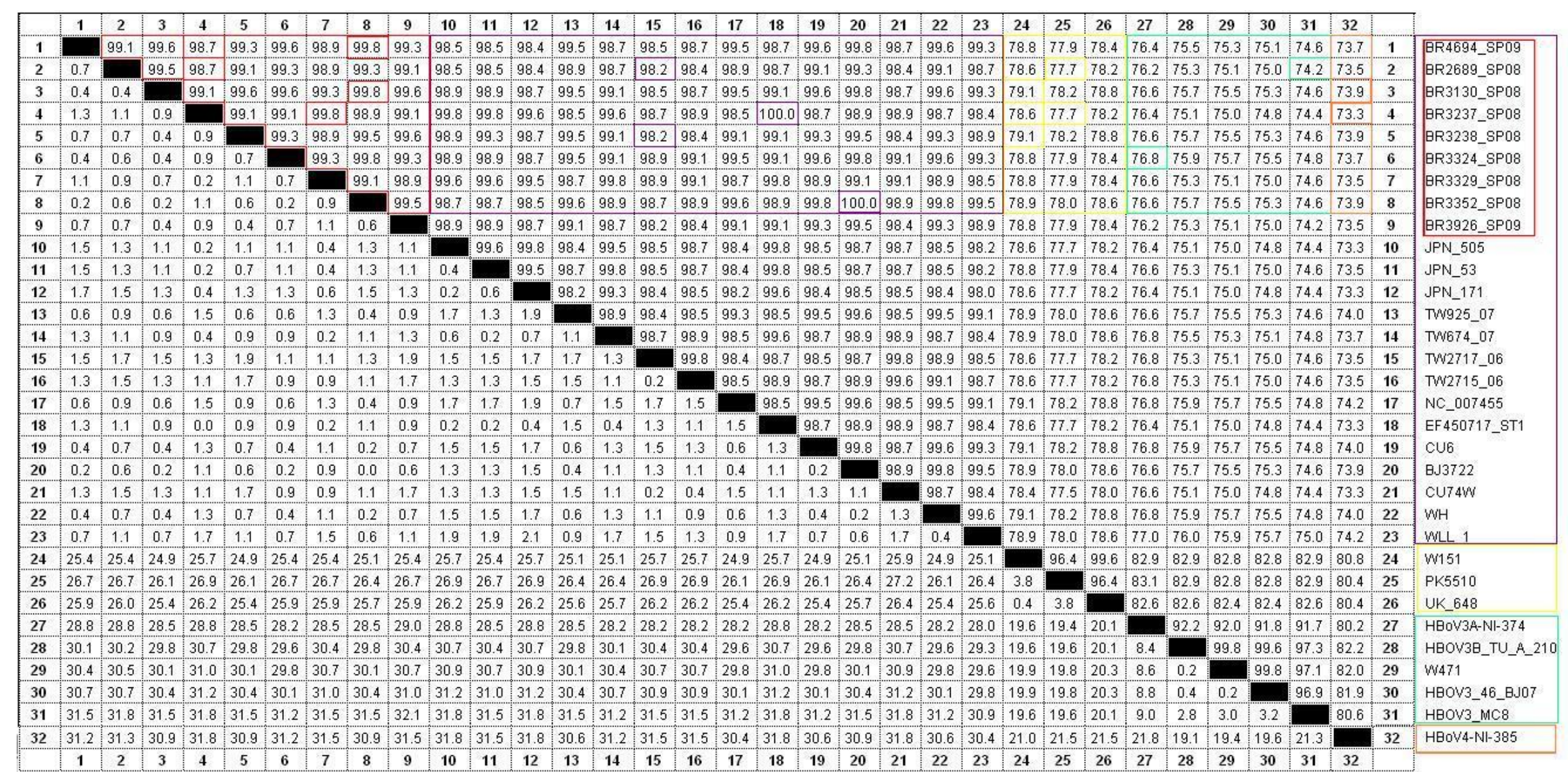

Figura 14 - Quadro de similaridade e divergência entre as sequências brasileiras e do GenBank. No quadro vermelho as amostras brasileiras são comparadas entre si, no quadro roxo são comparadas com as amostras representativas do HBoV-1 de outros paises, no quadro amarelo são comparadas com as de HBoV-2, no quadro verde são comparadas com as amostras representativas do HBoV-3 e no quadro laranja com as de HBoV-4. 


\subsection{Análise da Variabilidade de Aminoácidos}

Com o alinhamento dos nucleotideos gerados pelo sequenciamento, foram notadas 4 mutações, que ao serem comparadas com sequências do genbank, mostraram-se exclusivas de nossas amostras. Quando estes alinhamentos nucleotídicos foram traduzidos em aminoácidos e comparados com sequências do genbank representantes dos HBoVs espécies 1, 2, 3 e 4, foi observado que todas as mutações foram silenciosas (figura 15). 


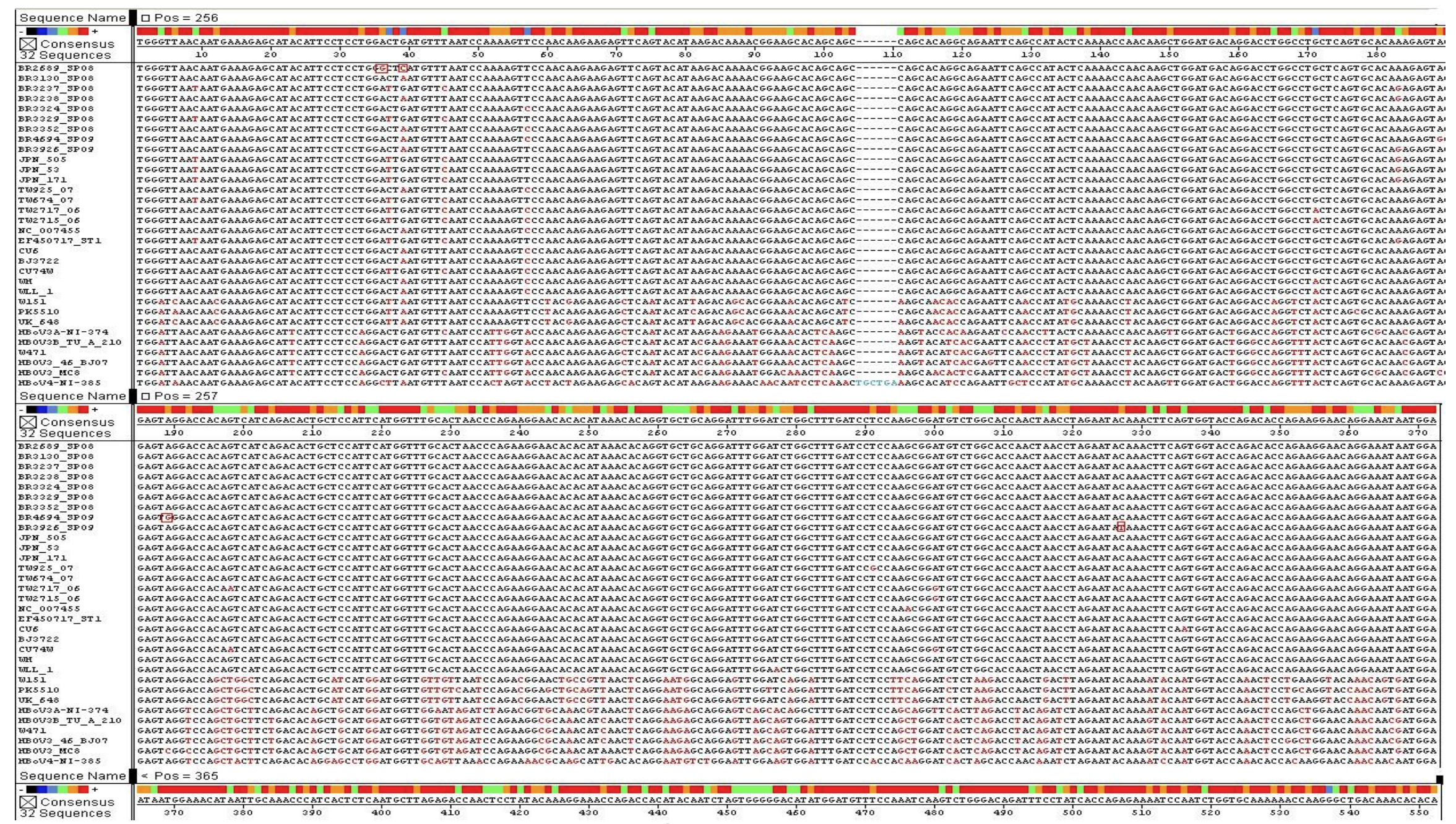

Figura 15 - Figura representativa do alinhamento de nucleotídeos, comparando as amostras brasileiras com as amostras de HBoV-1, 2, 3 e 4 retiradas do Genbank. Os quadrados em vermelho evidenciam as mutações existentes nas amostras brasileiras. 


\section{DISCUSSÃO}

O surgimento de novos vírus respiratórios circulantes no mundo e sua relevância clínica, levou, o Laboratório de Virologia Clínica e Molecular do Instituto de Ciências Biomédicas da Universidade de São Paulo, a associar-se ao Departamento de Pediatria da Santa Casa de Misericórdia de São Paulo para a realização de pesquisas envolvendo as doenças respiratórias em crianças atendidas no Serviço de Pediatria do HSCM-SP.

Nesses últimos 5 anos, trabalhos importantes sobre o $\mathrm{HBoV}$ foram desenvolvidos, resultando em cerca de 150 estudos com relevância mundial para a saúde infantil, sendo seis deles no Brasil. Porém, muitas características do HBoV ainda são desconhecidas, e mais estudos sobre sua circulação, sazonalidade e variabilidade são necessários.

Em nosso estudo foram demonstrados aspectos epidemiológicos importantes da infecção pelo HBoV durante dois anos consecutivos em uma região sub-tropical do Brasil, que é a cidade de São Paulo.

Primeiramente, nossos resultados mostram que o HBoV é um dos principais patógenos circulantes, em crianças abaixo de 2 anos de idade, internadas com sintomas de infecção respiratória aguda. De Fevereiro de 2008 a Dezembro de 2010, o HBoV foi detectado em 4,8\% das crianças abaixo de 2 anos de idade, as quais foram hospitalizadas por ITR, o que é condizente com a média demonstrada por outros autores ao redor do mundo que varia de 1,5\% no Canadá (Bastien et al., 2006) a $19 \%$ na Suécia (Allander et al., 2007). No Brasil foi detectado em $6 \%$ das amostras na Bahia (Souza et al., 2010), 3,4\% no Rio de Janeiro (Albuquerque et al., 2009) e 10,5\% em Ribeirão Preto-SP (Gagliardi et al., 2009).

Além disso, nossos dados revelaram que a maior incidência do HBoV ocorreu no outono e inverno de 2008, o que é consistente com os dados de diversos estudos que mostraram maior incidência nos meses de inverno (Smuts et al., 2006; Weissbrich et al., 2006; Sloots et al., 2006; Chung et al., 2006; Kesebir et al., 2006; Foulongne et al., 2006). No Brasil o único estudo que descreve uma padrão sazonal, é um estudo retrospectivo realizado com amostras coletadas no ano de 2005, e seus resultados indicaram o pico de ocorrência do HBoV nos meses do outono (Gagliardi et al., 2009), que é onde o nosso pico se inicia no ano de 2008. 
Porém, no ano de 2009 o HBoV distribuiu-se de modo mais uniforme, similarmente ao que foi relatado por um estudo realizado no Canadá que mostrou uma incidência regular para o HBoV (Bastien et al., 2006).

Nosso estudo demonstou que $55 \%$ das amostras positivas para $\mathrm{HBoV}$ estavam coinfectadas com outros vírus, corroborando os dados apresentados na literatura internacional. Todas as publicações envolvendo coinfecção de HBoV mostram altíssimas taxas de coinfecção, variando de 18\% na Suécia (Allander et al., 2005) até $90 \%$ na Tailândia (Fry et al., 2007). No Brasil foi relatado $81 \%$ de coinfecção do HBoV nas amostras de Ribeirão Preto-SP em 2005 (Gagliardi et al., 2009), $50 \%$ na Bahia (Souza et al., 2009) e $28,6 \%$ no Rio de Janeiro.

A análise filogenética de nossas amostras demostrou que apenas a espécie 1 do HBoV circula no Brasil, estando mais próximas das amostras asiáticas. Entretanto, tal afirmação pode ter um viés que é de não existirem muitas sequências da região VP1/VP2 do HBoV dos demais continentes depositados no genbank. Porém, nossos resultados corroboram com estudos realizados que demonstraram desde a descoberta do HBoV que o genótipo responsável por infecções respiratórias e a espécie 1(Schildgen et al., 2008).

A região $V P 1 / V P 2$ do $\mathrm{HBoV}$ é caracterizada por um baixo nível de polimorfismo, onde a maioria das variações genéticas, quando presentes, são relatadas no gene que codifica estas proteínas (Chieochansin et al., 2007), o que justificou a escolha desse gene como alvo do presente estudo. Nosso estudo encontrou 4 mutações exclusivas das amostras brasileiras, entretanto quando traduzidas, não originaram mudanças de aminoácidos constituíndo mutações silenciosas.

Chieochansin et al. (2007) em seu estudo, a partir da matriz de identidade obteve um intervalo de 98,7 a $100 \%$ para a seqüência da proteína VP1 e um intervalo de 98,2 a $100 \%$ para VP2. Em nosso estudo, a partir da matriz de identidade, obtivemos um intervalo entre 98,2 a $100 \%$ para sequência das proteínas VP1/VP2, resultado idêntico ao das amostras tailândesas. 


\section{CONCLUSÕES}

1) O HBoV é o quinto patógeno nas doenças respiratórias virais em crianças abaixo de 2 anos de idade, internadas com doença respiratória aguda, apresentando um comportamento endêmico na cidade de São Paulo.

2) As associações do $\mathrm{HBoV}$ com outros vírus respiratórios foram frequentes.

3) $\mathrm{O} \mathrm{HBoV}$ não apresentou uma sazonalidade definida nos dois anos de estudo, necessitando de um período maior de coleta.

4) Somente o HBoV-1 foi encontrado em circulação nas amostras provenientes de crianças abaixo de 2 anos de idade, internadas com doença respiratória aguda no HSCM-SP.

5) A comparação inter e intragrupo das sequências mostrou uma variação abaixo de $2 \%$.

6) O HBoV por ser um virus de DNA de fita simples, altamente conservado, não apresentou mutações significativas de nucleotideos e aminoacidos. 


\section{REFERÊNCIAS}

Allander T, Tammi M, Ericsson A, Bjerkner A, Tiveljung-Lindell A, Andersson B. Cloning of a human parvovirus by molecular screening of respiratory tract samples. Proc Natl Acad Sci. 2005;102:12891-12896.

Allander T, Jartti T, Gupta S, et al. Human bocavirus and acute wheezing in children. Clin Infect Dis. 2007;44(7):904-10.

Allander T. Human bocavirus. J Clin Virol. 2008;41:29-33.

Albuquerque MC, Rocha LN, Benati FJ, Soares CC, Maranhão AG, Ramírez ML, et al. Human bocavirus infection in children with gastroenteritis, Brazil. Emerg Infect Dis. 2007;13:1756-8.

Albuquerque MC, Pena GPA, Varella RB, Gallucci G, Erdman D, Santos N. Novel Respiratory Virus Infections in Children, Brazil. Emerg Infect Dis. 2009;15 (5):806-8.

Arnold JC, Singh KK, Spector SA, et al. Human bocavirus: prevalence and clinical spectrum at a children's hospital. Clin Infect Dis. 2006;43(3):283-8

Arthur JL, Higgins GD, Davidson GP, et al. A novel bocavirus associated with acute gastroenteritis in Australian children. PLoS Pathog. 2009;5(4):e1000391.

Bastien N, Brandt K, Dust K, et al. Human bocavirus infection, Canada. Emerg Infect Dis. 2006;12(5):848-50.

Bastien N, Chui N, Robinson JL, et al. Detection of human bocavirus in Canadian children in a 1-year study. J Clin Microbiol. 2007;45(2):610-3.

Benguigui Y. El control de las IRA en America: actvidades y perspectivas. In: Noticias Sobre IRA. 1994; Grupo CID OPS/OMS, 27: 4-5.

Berns, K. I. (1996). Parvoviridae: The viruses and their replication. In Fields Virology, 3rd edn, pp. 2173-2197. Edited by B. N. Fields, D. M. Knipe \& P. M. Howley. Philadelphia: Lippincott-Raven.

*De acordo com: International Committee of Medical Journal Editors. Uniform requirements for manuscripts submitted to Biomedical Journal: sample references. Available from: http://www.icmje.org [2007 May 22]. 
Birnbaum HG, Morley M, Greenberg PE, et al. Economic burden of respiratory infections in an employed population. Chest. 2002;122(2):603-11.

Brieu N, Gay B, Segondy M, et al. Electron microscopy observation of human bocavirus (HBoV) in nasopharyngeal samples from HBoV-infected children. J Clin Microbiol 2007;45(10):3419-20

Bosis S, Esposito S, Niesters HG, et al. Role of respiratory pathogens in infants hospitalized for a first episode of wheezing and their impact on recurrences. Clin Microbiol Infect. 2008;14(7):677-8)

Chieochansin T, Chutinimitkul S, Payungporn S, et al. Complete coding sequences and phylogenetic analysis of Human Bocavirus (HBoV). Virus Res. 2007;129(1):547.

Choi EH, Lee HJ, Kim SJ, et al. The association of newly identified respiratory viruses with lower respiratory tract infections in Korean children, 2000-2005. Clin Infect Dis. 2006;43(5):585-92.

Christensen A, Nordbo SA, Krokstad S, et al. Human bocavirus commonly involved in multiple viral airway infections. J Clin Virol 2008;41(1):34-7.

Chow BD, Huang YT, Esper FP. Evidence of human bocavirus circulating in children and adults, Cleveland, Ohio. J Clin Virol. 2008;43(3):302-6.

Chow BDW, Esper FP. The Human Bocaviruses: A Review and Discussion of Their Role in Infection. Clin Lab Med. 2009; 29:695-713

Durigon GS, Oliveira DBL, Vollet SB, et al. Hospital-acquired human bocavirus in infants. J Hosp Infect. 2010; XXX:1-3.

Fry AM, Lu X, Chittaganpitch $M$, et al. Human bocavirus: a novel parvovirus epidemiologically associated with pneumonia requiring hospitalization in Thailand. J Infect Dis. 2007;195(7):1038-45.

Foulongne V, Olejnik $\mathrm{Y}$, Elaertz $\mathrm{S}$, Perez $\mathrm{V}$, Rodière $\mathrm{M}$, Segondy $\mathrm{M}$. Human bocavirus in French children. Emerg Infect Dis. 2006;12:1251-3.

Fredericks DN, Relman DA. Sequence-based identification of microbial pathogens: a reconsideration of Koch's postulates. Clin Microbiol Rev. 1996;9(1):18-33. 
Gagliardi TB, Iwamamoto MA, Paula FE, Proenc JL, Modena A, Saranzo AM, Criado MF, Acrani GO, Camara AA, Cintra Al, Arruda E. SHORT REPORT Human bocavirus respiratory infections in children. Epidemiol. Infect. 2009; 137: 1032-1036.

Gendrel D, Guedj R, Pons-Catalano C, et al. Human bocavirus in children with acute asthma. Clin Infect Dis. 2007;45(3):404-5.

Gurda BL, Parent KN, Bladek H, et al. Human Bocavirus Capsid Structure: Insights into the Structural Repertoire of the Parvoviridae. J. Virol. 2010; 84(12):5880-9.

Hindiyeh MY, Keller N, Mandelboim M, et al. High rate of human bocavirus and adenovirus coinfection in hospitalized Israeli children. $J$ Clin Microbiol. 2008;46(1):334-7.

Jacques $\mathrm{J}$, Moret $\mathrm{H}$, Renois $\mathrm{F}$, et al. Human bocavirus quantitative DNA detection in French children hospitalized for acute bronchiolitis. J Clin Virol. 2008;43(2):142-7.

Kantola K, Hedman L, Allander T, Jarti T, Lehtinen P, Ruuskanen O, Hedman L, Soderlund-Venermo M. Serodiagnosis of human bocavirus Infection. Clin Infect Dis. 2008;46:540-6.

Kaplan NM, Dove W, Abu-Zeid AF, et al. Human bocavirus infection among children, Jordan. Emerg Infect Dis. 2006;12(9):1418-20.

Kapoor A, Slikas E, Simmonds P,et al. A Newly Identified Bocavirus Species in Human Stool. J. Infect. Dis. 2009;199:196-200.

Kesebir D, Vazquez M, Weibel C, Shapiro ED, Ferguson nD, Landry ML, Khan JS. Human bocavirus infection in young children in the United States: molecular epidemiological profile and clinical characteristics of a newly emerging respiratory vírus. J Infect Dis. 2006;1276-1282.

Kupfer B, Vehreschild J, Cornely O, et al. Severe pneumonia and human bocavirus in adult. Emerg Infect Dis. 2006;12(10):1614-6.

Linstow MLV, Hogh M, Hogh B. Clinical and epidemiologic characteristics of human bocavirus in Danish infants: results from a prospective birth cohort study. Pediatr Infect Dis J. 2008;27(10):897-902. 
Lu X, Chittaganpitch M, Olsen SJ, Mackay IM, Sloots TP, Fry AM, Erd- man DD. Real-time PCR assays for detection of bocavirus in human specimens. J Clin Microbiol. 2006;44:3231-5.

Ma X, Endo R, Ishiguro $\mathrm{N}$, et al. Detection of human bocavirus in Japanese children with lower respiratory tract infections. J Clin Microbiol. 2006;44(3):1132-4.

Maggi $F$, Andreoli E, Pifferi M, et al. Human bocavirus in Italian patients with respiratory diseases. J Clin Virol. 2007;38(4):321-5.

Manning A, Russell V, Eastick K, Leadbetter GH, Hallam N, Templeton K, Simmonds $P$. Epidemiological profile and clinical associations of human bocavirus and other human parvoviruses. J Infect Dis. 2006;194:1283-90.

Merrill C, Elixhauser A. Hospitalization in the United States, 2002: HCUP fact book no. 6. Rockville (MD): Agency for Healthcare Research and Quality; 2005.

Monteny M, Niesters HG, Moll HA, et al. Human bocavirus in febrile children, The Netherlands. Emerg Infect Dis. 2007;13(1):180-2.

Moreno CM, Solís YO, O'Ryan MG. Human bocavirus: studies in the literature and in Chile. Rev Chilena Infectol. 2009; 26 (6): 504-10.

Naghipour M, Cuevas LE, Bakhshinejad T, et al. Human bocavirus in Iranian children with acute respiratory infections. J Med Virol. 2007;79(5):539-43.

Neske F, Blessing K, Tollmann F, et al. Real-time PCR for diagnosis of human bocavirus infections and phylogenetic analysis. J Clin Microbiol. 2007;45(7):2116-22.

Pinner RW, Teutsch SM, Simonsen L, Klug LA, Graber JM, Clarke MJ, Berkelman RL. Trends in infectious diseases mortality in the United States. JAMA. 1996; 275:189-193.

Qu XW, Duan ZJ, Qi ZY, et al. Human bocavirus infection, People's Republic of China. Emerg Infect Dis. 2007;13(1):165-8.

Regamey N, Frey U, Deffernez C, et al. Isolation of human bocavirus from Swiss infants with respiratory infections. Pediatr Infect Dis J. 2007;26(2):177-9. 
Santos N, Peret TCT, Humphreya CD, et al. Human bocavirus species 2 and 3 in Brazil. J Clin Virol. 48 (2010) 127-130.

Schenk T, Strahm B, Kontny U, et al. Disseminated bocavirus infection after stemcell transplant. Emerg Infect Dis. 2007;13(9):1425-7.

Schildgen O, Muller A, Allander T, et al. Human bocavirus: passen- ger or pathogen in acute respiratory tract infections? Clin Microbiol Rev. 2008; $21: 291-304$.

Selwyn BJ. The epidemiology of acute respiratory tract infection in young children: comparison of findings from several developing countries. Rev Infect Dis. 1990; 12 : 870-88.

Sloots TP, McErlean P, Speicher DJ, et al. Evidence of human coronavirus HKU1 and human bocavirus in Australian children. J Clin Virol. 2006;35(1):99-102.

Smuts $\mathrm{H}$, Hardie D. Human bocavirus in hospitalized children, South Africa. Emerg Infect Dis. 2006;12(9):1457-8.

Söderlund-Venermo M, Lahtinen A, Jartti T, Hedman L, Kemppainen K, Lehtinen P, Allander T, Ruuskanen O, Hedman K. Clinical Assessment and Improved Diagnosis of Bocavirus-induced Wheezing in Children, Finland. Emerg Infect Dis. 2009;15(9): 1423-30.

Souza EL, Ramos JG, Proença-Módena JL, Diniz A, Carvalho G, Ciuffo I, AraújoNeto CA, Andrade SC, Souza LS, Arruda E, Silva L. Human Bocavirus in Very Young Infants Hospitalized with Acute Respiratory Infection in Northeast Brazil. J Trop Pediatr.2010;56(2):125-7.

Tan BH, Lim EA, Seah SG, et al. The incidence of human bocavirus infection among children admitted to hospital in Singapore. J Med Virol. 2009;81(1):82-9.

Vallet C, Pons-Catalano C, Mandelcwajg A, Wang A, Raymond J, Lebon P, Gendrel D. Human Bocavirus: A Cause of Severe Asthma Exacerbation in Children. J Pediatr. 2009;155:286-8.

Vicente D, Cilla G, Montes M, et al. Human bocavirus, a respiratory and enteric virus. Emerg Infect Dis. 2007;13(4):636-7.

Weissbrich B, Neske F, Schubert J, et al. Frequent detection of bocavirus DNA in German children with respiratory tract infections. BMC Infect Dis. 2006;6:109. 
Zhi, N., I. P. Mills, J. Lu, S. Wong, C. Filippone, and K. E. Brown. 2006. Molecular and functional analyses of a human parvovirus B19 infectious clone demonstrates essential roles for NS1, VP1, and the 11-kilodalton protein in virus replication and infectivity. J. Virol. 80:5941-5950. 